\title{
Business Case for Compressed Natural Gas in Municipal Fleets
}

Technical Report NREL/TP-7A2-47919 June 2010

Caley Johnson

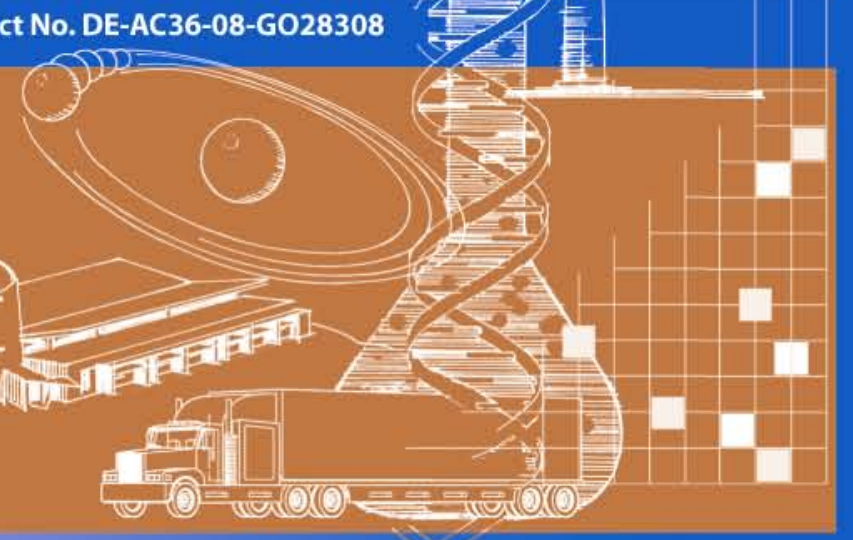




\section{Business Case for Compressed Natural Gas in Municipal Fleets}

\section{Caley Johnson}

Prepared under Task No. FC08.0032

National Renewable Energy Laboratory

1617 Cole Boulevard, Golden, Colorado 80401-3393

303-275-3000 • www.nrel.gov

NREL is a national laboratory of the U.S. Department of Energy

Office of Energy Efficiency and Renewable Energy

Operated by the Alliance for Sustainable Energy, LLC

Contract No. DE-AC36-08-GO28308
Technical Report NREL/TP-7A2-47919 June 2010

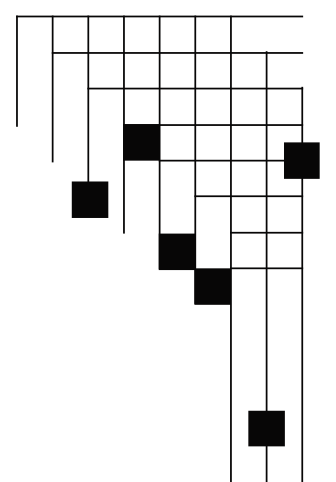




\section{NOTICE}

This report was prepared as an account of work sponsored by an agency of the United States government. Neither the United States government nor any agency thereof, nor any of their employees, makes any warranty, express or implied, or assumes any legal liability or responsibility for the accuracy, completeness, or usefulness of any information, apparatus, product, or process disclosed, or represents that its use would not infringe privately owned rights. Reference herein to any specific commercial product, process, or service by trade name, trademark, manufacturer, or otherwise does not necessarily constitute or imply its endorsement, recommendation, or favoring by the United States government or any agency thereof. The views and opinions of authors expressed herein do not necessarily state or reflect those of the United States government or any agency thereof.

Available electronically at http://www.osti.gov/bridge

Available for a processing fee to U.S. Department of Energy and its contractors, in paper, from:

U.S. Department of Energy

Office of Scientific and Technical Information

P.O. Box 62

Oak Ridge, TN 37831-0062

phone: 865.576 .8401

fax: 865.576 .5728

email: mailto:reports@adonis.osti.gov

Available for sale to the public, in paper, from:

U.S. Department of Commerce

National Technical Information Service

5285 Port Royal Road

Springfield, VA 22161

phone: 800.553.6847

fax: 703.605.6900

email: orders@ntis.fedworld.gov

online ordering: http://www.ntis.gov/ordering.htm 


\section{Acknowledgements}

Funding for this report came from the Clean Cities activity within the U.S. Department of Energy Vehicle Technologies Program.

This report has greatly benefitted from the time and insight shared through personal communications with various fleet operators and industry specialists as indicated in the bibliography.

The author owes a particular gratitude to Rob Adams with Marathon Technical Services. Rob shared his extensive knowledge of building and operating compressed natural gas refueling stations by patiently answering numerous questions, sharing his station cost calculator, and reviewing multiple drafts.

All assumptions and any inaccuracies are the responsibility of the author and not the experts acknowledged above. 


\section{Introduction}

Compressed natural gas $(\mathrm{CNG})$ vehicle projects can be highly profitable, or they can lose money, depending on numerous aspects of the fleet and station. To assist fleets and businesses in evaluating the profitability of potential CNG projects, the National Renewable Energy Laboratory (NREL) built the CNG Vehicle and Infrastructure Cash-Flow Evaluation (VICE) model. The VICE model demonstrates the relationship between project profitability and fleet operating parameters. This report describes how NREL used the VICE model to establish guidance for fleets making decisions about using CNG.

The first section establishes a base-case scenario for three fleets that commonly use CNGtransit buses, school buses, and refuse trucks. This base-case tries to represent the average or most-common parameters affecting the $\mathrm{CNG}$ project's profitability for average fleets of each type.

The second section uses the model to show how specific project parameters (such as station cost or price of fuel) change profitability from the base-case. The section then prioritizes these parameters to help fleet operators understand the most important factors affecting the business case of the project. Through a question-and-answer format, this section presents common CNGrelated questions answered by NREL using the VICE model.

The business case targets municipal governments, which operate fleets suited well for CNG vehicles because they drive circular routes that enable refueling at the same station. These fleets are transit buses, school buses, and refuse trucks. Municipal governments are also targeted because their primary goal is to improve their residents' quality of life. This goal allows the government to utilize all the advantages of CNG, including long-term cost-effectiveness, moreconsistent operational costs, increased energy security, reduced greenhouse gas emissions, reduced local air pollution, and reduced noise pollution. A forthcoming report will focus on private fleets that are suited well for CNG, such as taxi cabs and delivery trucks. 


\section{Table of Contents}

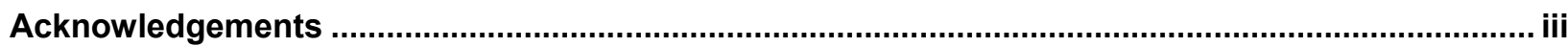

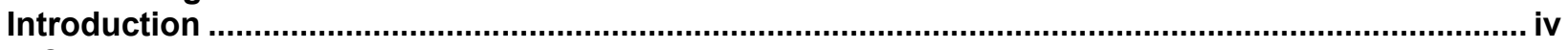

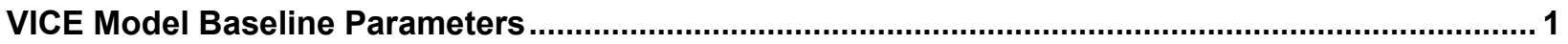

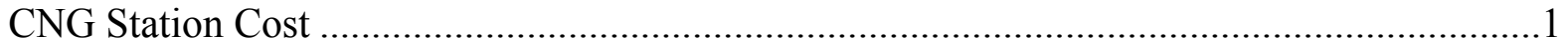

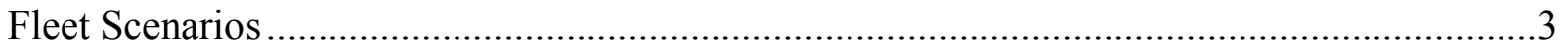

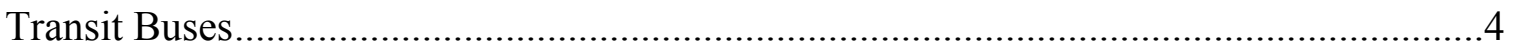

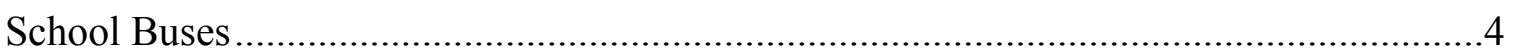

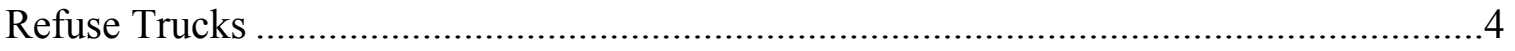

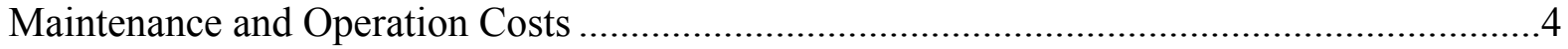

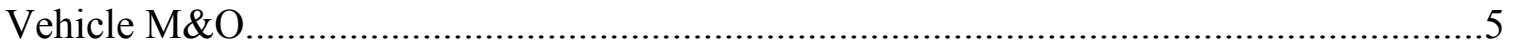



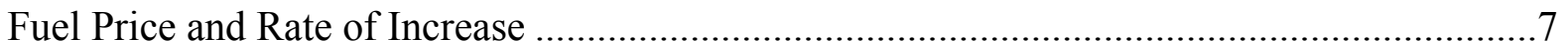

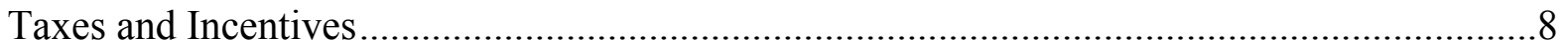

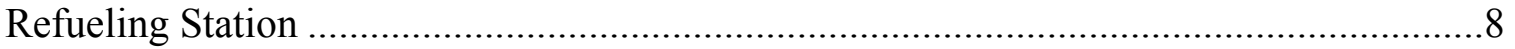

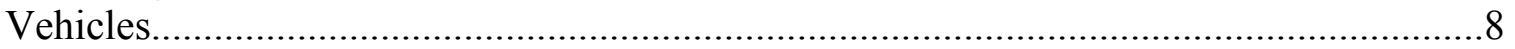

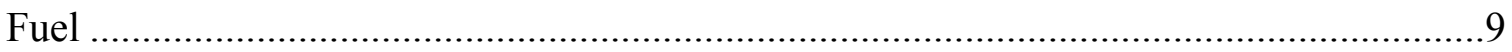

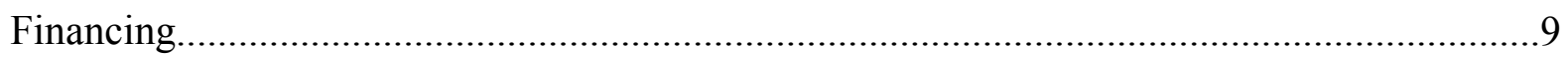

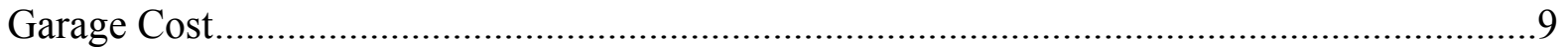

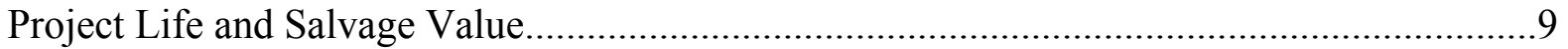

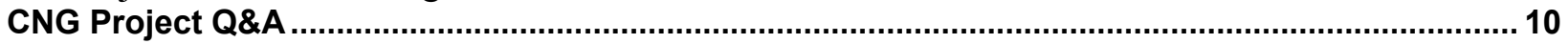

How do I know if a CNG project makes financial sense? .............................................. 10

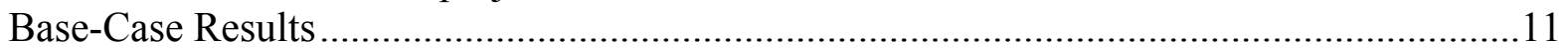

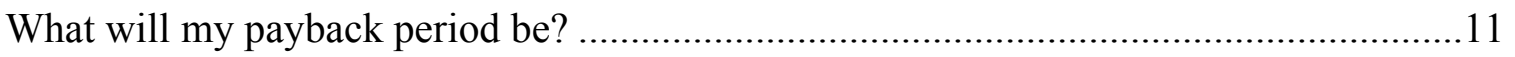

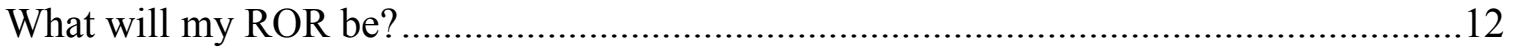

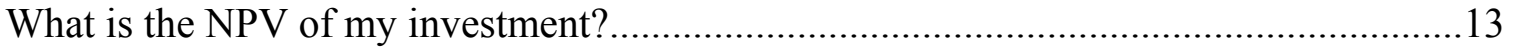

What is the minimum number of vehicles required to break even? ..............................14

Variations in Fuel Expenditures..................................................................................... 14

How many miles per year do I need to drive my vehicles to break even? .......................15

What will a change in diesel prices do to my payback period? ......................................16

What does the composition of my fleet do to my project economics? ............................17

What happens as my vehicle efficiency changes? ....................................................... 18

What if the $\$ 0.55 / \mathrm{DGE}, 80 \%$ vehicle incremental cost, or $\$ 50,000$ station tax credit is taken away or not passed along?...................................................................... 19

What if I have to pay fuel excise taxes on diesel but not CNG? ....................................19

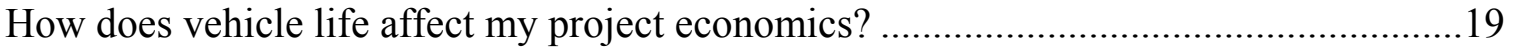

Changes in Upfront Costs .............................................................................................20

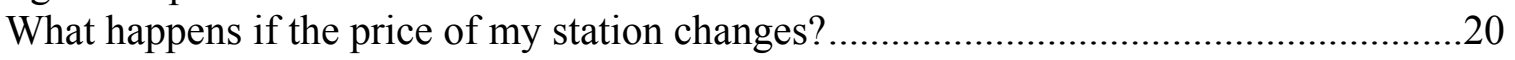

What happens as my vehicle incremental cost changes? ..........................................21

What if I receive a grant from the Federal Transit Administration? ...............................22

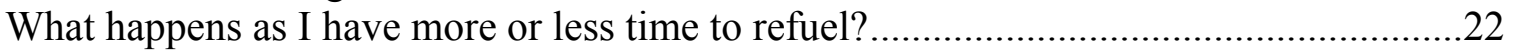

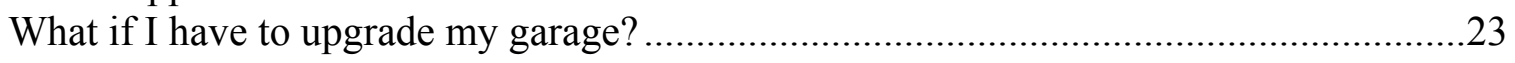

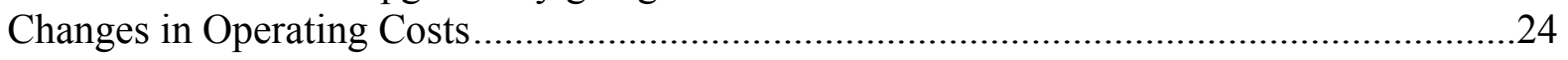

What happens if my vehicle maintenance costs change? ..........................................24

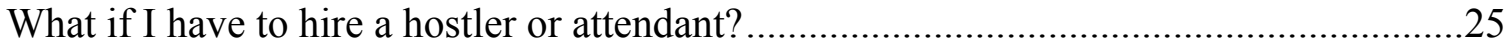

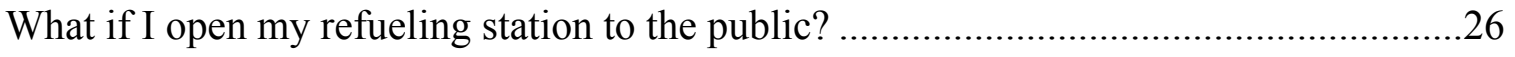


How do electricity prices change my project economics? ..........................................27

How do station maintenance costs change my project economics? ...............................27

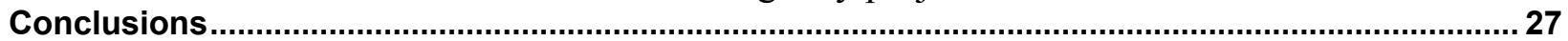

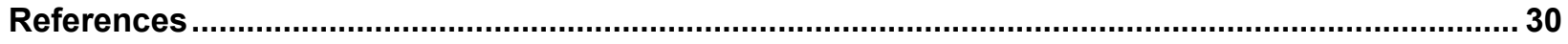

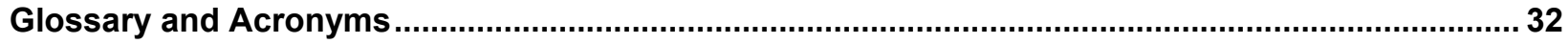




\section{VICE Model Baseline Parameters}

This analysis uses multiple input variables to simulate the financial circumstances faced by municipal fleets. In this section, average or common values are used to establish a baseline scenario for common operating circumstances. This scenario provides a snapshot from which we can test the sensitivity of $\mathrm{CNG}$ project economics to changes in various parameters.

\section{CNG Station Cost}

Station cost is derived by a cost calculator constructed by Rob Adams with Marathon Technical Services (Marathon). The calculator replicates a buffered fast-fill station, which is best suited for quickly fueling large numbers of heavy-duty, high-fuel-capacity vehicles. It is recognized that under scenarios with low throughput and large refueling windows, a time-fill station might be preferred. However, under these scenarios, the calculator takes into account the reduction in equipment needed by reducing the overall cost of the station close to that of a comparable timefill station. Therefore, the cost estimate is realistic over a wide range of station sizes.

Constants in the calculator are as follows:

- Spare ratio is $10 \%$. This means that $10 \%$ of the fleet is expected to not refuel on any given day.

- Station inlet pressure is 100 pound-force per square inch gauge (psig)

- Compressor package is a fully enclosed electric drive

- Dryer consists of a single manual tower for stations dispensing fewer than 30,000 dieselgallon equivalents (DGE) per month (depending on fleet type) and a fully automatic twin tower for stations dispensing more than 30,000 DGEs per month.

- The system is designed to store $\mathrm{CNG}$ at $5500 \mathrm{psig}$

- Installation costs are assumed to be $50 \%$ of the equipment costs based on numerous Marathon projects of a variety of sizes.

Variables in the station cost calculator are throughput (amount of fuel dispensed per month), refueling window (number of hours per day when vehicles are available to refuel), and peak capacity (flow required to keep the fleet fueled). These parameters affect the size and number of tanks, compressors, and supporting equipment. Throughput is calculated from the VICE model by dividing the number of vehicles by the average fuel economy of the fleet. The refueling window is fleet-dependent, and the following scenarios were used for the calculator:

- Transit bus fleets were assumed to have a refueling window of 6 hours based on significant Marathon industry project experience.

- School bus fleets were assumed to have a refueling window of 12 hours. This figure comes from interviewing school fleet managers (Andre 2009 and Linder 2009).

- Refuse truck fleets were assumed to have a refueling window of 12 hours. This figure comes from the director of numerous refuse fleets (Lemmons 2009). 
- Combining two fleets allows them to keep the larger of the two refueling windows. This assumption is conservative; in actuality, it would probably expand the refueling window and lower station requirements further for a given number of vehicles. We used a conservative assumption because we do not know of anybody who has optimized this refueling window (by staggering their fleets) to date.

- The scenario where three fleet types share a central refueling station assumes the refueling window is 12 hours a day. This is a conservative assumption when the schedules of all three fleets are taken into account, but it is used because it retains flexibility for the fleets to refuel at more-convenient times.

Test runs were then done with the calculator, and the results were plotted to establish a relationship between the size of the station and its cost. A linear trendline was then fitted to these lines, and equations were derived to represent the best relationship between a station's size and cost. The trendlines are shown in Figure 1, and their matching equations were entered in the VICE model to derive station cost.

It should be noted that the school station is less expensive for the practical range of a school fleet, yet its costs rise at a steeper rate than the others because it uses equipment that cannot be scaled up as efficiently. The school station is only charted up to 65,000 DGEs per month because school fleets use less fuel, so no scenarios were modeled that involved a school fleet using more than this amount of fuel. Refuse stations achieve greater economies of scale than transit stations - presumably because their larger refueling window allows for greater increase of throughput without a corresponding increase in equipment. 


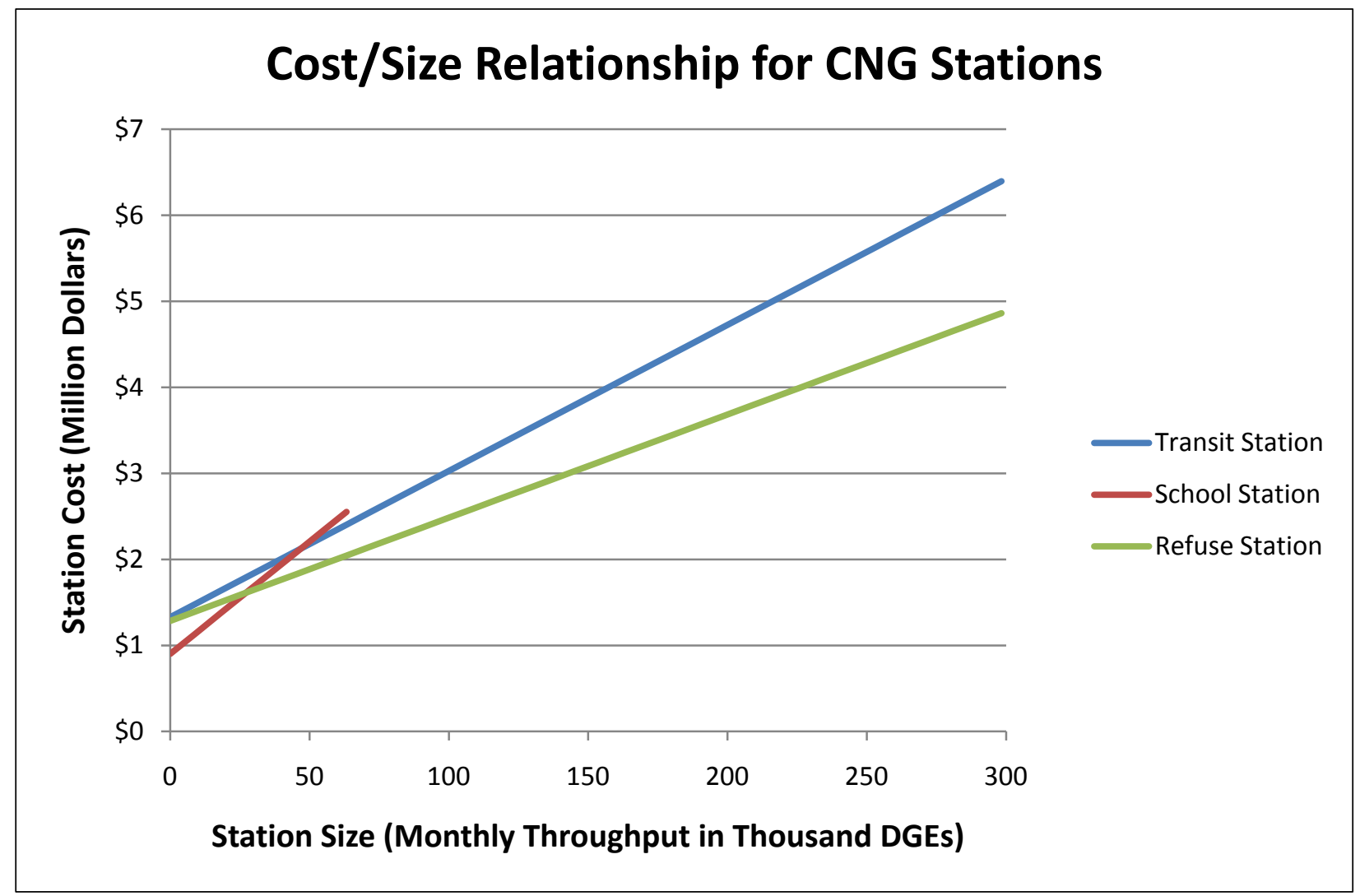

Figure 1. The relationship between the size of a CNG station and its cost. It should be noted that the upper end of the station throughput range $(300,000 \mathrm{DGE})$ is uncommon.

\section{Fleet Scenarios}

The VICE model considers seven different fleets with the following parameters:

Table 1. Seven Modeled Fleets and Their Parameters

\begin{tabular}{|c|c|c|c|c|c|c|}
\hline $\begin{array}{c}\text { Scen- } \\
\text { ario }\end{array}$ & Fleet Type & $\begin{array}{c}\text { Avg. } \\
\text { VMT }\end{array}$ & $\begin{array}{c}\text { FE Diesel } \\
(\mathbf{m p g})\end{array}$ & $\begin{array}{c}\text { FE CNG } \\
(\mathbf{m p D G E})\end{array}$ & $\begin{array}{c}\text { Incremental } \\
\text { Cost }\end{array}$ & $\begin{array}{c}\text { Vehicle } \\
\text { Life }\end{array}$ \\
\hline 1 & Transit Buses & 35,286 & 3.27 & 3.02 & $\$ 50,502$ & 15 \\
\hline 2 & School Buses & 12,000 & 7.00 & 6.13 & $\$ 31,376$ & 15 \\
\hline 3 & Refuse Trucks & 25,000 & 2.80 & 2.51 & $\$ 30,295$ & 12 \\
\hline 4 & $1 / 2$ Transit, 1/2 School & 23,643 & 5.14 & 4.57 & $\$ 40,939$ & 15 \\
\hline 5 & $1 / 2$ Transit, 1/2 Refuse & 30,143 & 3.04 & 2.76 & $\$ 40,399$ & 14 \\
\hline 6 & $1 / 2$ School, 1/2 Refuse & 18,500 & 4.90 & 4.32 & $\$ 30,836$ & 14 \\
\hline 7 & 1/3 Each & 24,095 & 4.36 & 3.88 & $\$ 37,391$ & 14 \\
\hline
\end{tabular}

The parameters for the combination fleets (scenarios 4 through 7) are weighted averages according to their composition by the first three fleets. Parameters for the first three fleets are listed below. 


\section{Transit Buses}

- The average vehicle-miles traveled (VMT) of transit buses is 35,286 miles/year derived from tables 8 and 9 in American Public Transit Association (APTA) 2009.

- The average fuel economy of diesel buses in the United States is $3.27 \mathrm{mpg}$, which is calculated from tables 8, 9, and 12 in APTA 2009.

- The average fuel economy of CNG buses is 3.02 miles per DGE (mpDGE), which is calculated from tables 8, 9, and 15 in APTA 2009.

- Incremental cost $(\$ 50,502)$ is an average of the incremental costs found in Chandler et al. 2006 (Table 6 adjusted for inflation) and from an interview with Bob Antila (Antila 2009).

- Bus lifetime (15 years) is the average retirement age of buses as reported in table ES-2 in the Federal Transit Administration's study on the useful life of buses (FTA 2007).

\section{School Buses}

- Average VMT of a school bus is 12,000 miles/year (American School Bus Council 2009).

- Average fuel economy of a diesel school bus is $7 \mathrm{mpg}$ (American School Bus Council 2009 and Andre 2009).

- Fuel economy of a CNG bus is $6.13 \mathrm{mpDGE}$, which is calculated as a $12.5 \%$ reduction in efficiency from diesel school buses (Linder 2009).

- Incremental cost is $\$ 31,376$ (average of four sources-Linder 2009, Leonard et al. 2001, Cohen 2005, and USCS 2003 — where the latter three sources have been adjusted for inflation).

- Bus lifetime (15 years) is taken from School Bus Fleet Magazine's 2009 Maintenance Survey.

\section{Refuse Trucks}

- Average VMT of a refuse truck is 25,000 miles/year (Gordon et al. 2003).

- Fuel economy of a diesel refuse truck is $2.8 \mathrm{mpg}$ (Gordon et al. 2003).

- Fuel economy of a CNG refuse truck is $2.51 \mathrm{mpDGE}$, which is calculated as a $10.5 \%$ reduction in efficiency from diesel refuse trucks (Gordon et al. 2003).

- Incremental cost of a CNG refuse truck is \$30,295 (average of three sources: Lemmons 2009, Andrews 2009, and San Antonio 2009).

- Useful life of a refuse truck is 12 years (Gordon et. al. 2003 and Lemmons 2009).

\section{Maintenance and Operation Costs}

This section describes some maintenance and operation (M\&O) costs associated with vehicles and CNG stations. 


\section{Vehicle M\&O}

Maintenance and operation costs for a CNG bus are considered the same as those for a diesel bus because evidence supports both a cost decrease (Chandler et. al 2006) and a cost increase (CVEF 2010) when switching from CNG to diesel. The unclear cost signal portrayed in these studies represents a factor that is in flux due to maintenance learning curves, new diesel emissions equipment, a sub-competitive CNG parts market, and other factors. This cost parity for CNG buses is assumed to apply to CNG refuse trucks as well, which is supported by Engle (2010).

\section{CNG Station M\&O}

The VICE model assumes that M\&O costs for a diesel refueling station are wrapped into the retail price of diesel fuel because the fuel retailer needs to cover these costs to stay in business. Natural gas prices, on the other hand, do not include CNG station costs because most natural gas is sold to the non-transportation market. Therefore, all $\mathrm{M} \& \mathrm{O}$ costs for the CNG station are incremental.

Maintenance costs of a CNG station include the cost of parts, consumables, labor, breakdowns, and on-call staff to keep a station functioning properly. The labor is generally provided by a technician that is "on call" for a number of stations in a given area. The estimated annual maintenance costs used in the model are $5 \%$ of the upfront cost of a large station, rising to $8 \%$ of the upfront costs of a small station. This assumption came from Rob Adams, who uses this as a rule of thumb when bidding on maintenance contracts. A rule-of-thumb estimate was needed because maintenance costs vary so widely according to station, and the rule of thumb takes most of these variations into account. This estimation technique is based on the idea that when more money is spent on equipment, more money must be spent to keep up and replace the equipment. It also takes into account economies of scale.

Rob Adams' estimation technique was chosen not only for its logic and simplicity, but because it splits the difference between two other maintenance estimates that we received from other sources. Figure 2 compares the three estimates on a monthly cost-per-station-size scale. It is not surprising that the three estimates are so different because the contractors rely heavily on stationspecific circumstances that were not available for these general estimates. Given the choice between three qualified industry experts, we selected the middle estimate.

Next, the "8\% to 5\%" was distilled into an equation so it could be inserted into the model. As shown in Figure 2, a polynomial equation fit the line very well for the range from 0 to 300,000 DGE throughput. After that, it was set to rise $0.06 \%$ per DGE. The polynomial equation used in the model is:

$$
\mathrm{Y}=-2.225 * 10^{-7} \mathrm{X}^{2}+0.1257 \mathrm{X}+7,014.3
$$




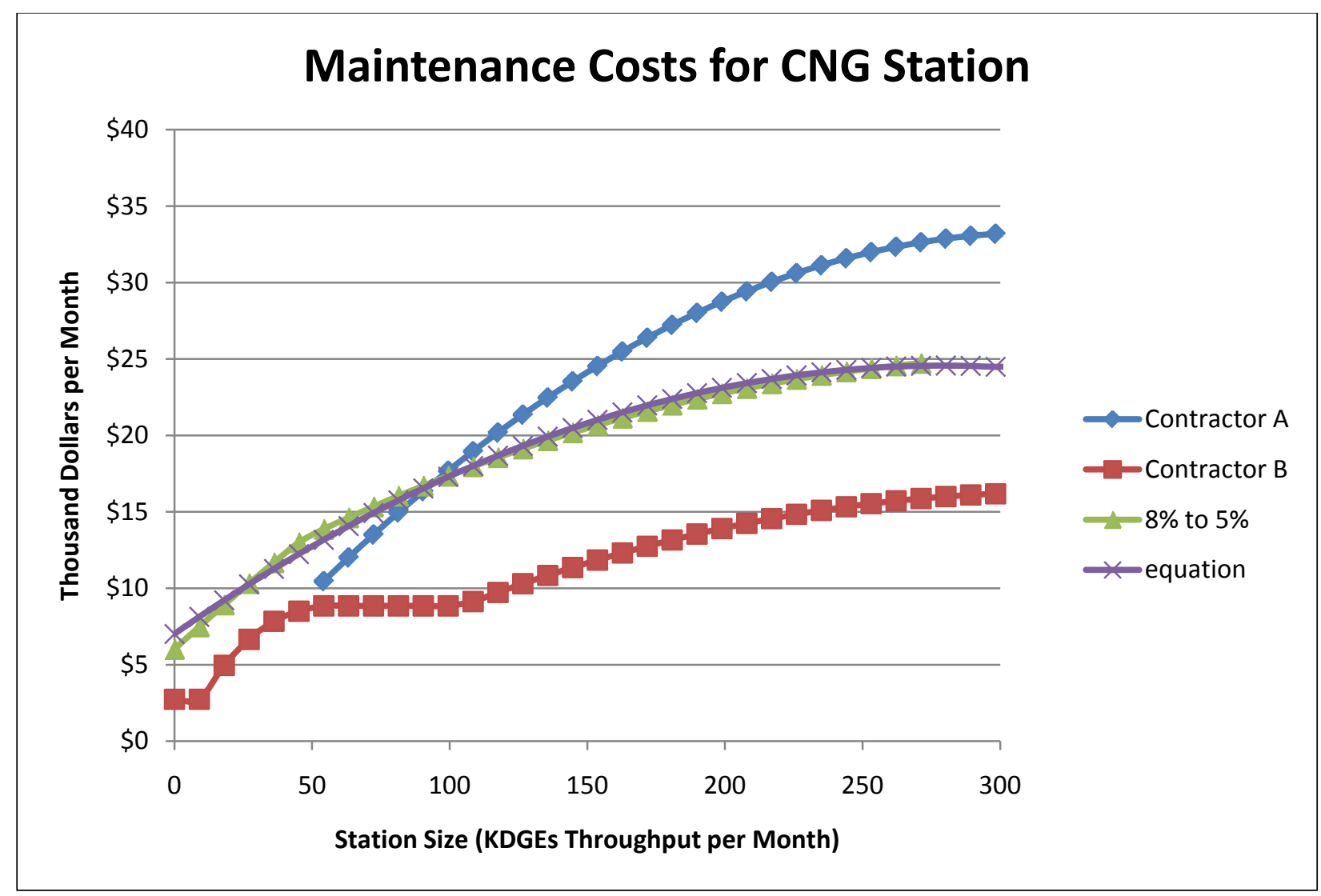

Figure 2. Three M\&O contractors' estimates at maintenance costs according to station size with the equation used in the VICE model

Electricity is the primary operation cost considered in the base-case scenario. "Commercial" electricity clients in most states pay both an energy charge and a capacity charge (often called demand charge) for electricity. The capacity charge reflects how much electricity the utility needs to be prepared to produce for you and therefore depends on how quickly you draw electricity from the grid, which is especially important for CNG stations because they can have a very large ampere draw. The model assumes the energy charge to be $\$ 0.10 / \mathrm{kWh}$, which is between the mid-peak and on-peak prices in California in January 2009. The assumed capacity charge is $\$ 12 / \mathrm{kW} / \mathrm{month}$ for the same reasons. The combined electricity charges result in different monthly electricity prices for the three fleets based on throughput, as seen in Figure 3. The two trendlines were converted to equations and inserted into the model. It should be noted that the transit station's electric costs start higher than the refuse and school's cost because its smaller refueling window requires larger compressors, which leads to higher electric capacity requirements. This demand charge represents a fixed cost portion of the electric bill. This difference is minimized as throughput increases because the variable cost portion of the electrical bill (the energy charge) becomes more pronounced, which decreases the previous advantage that these stations had over the transit station. 


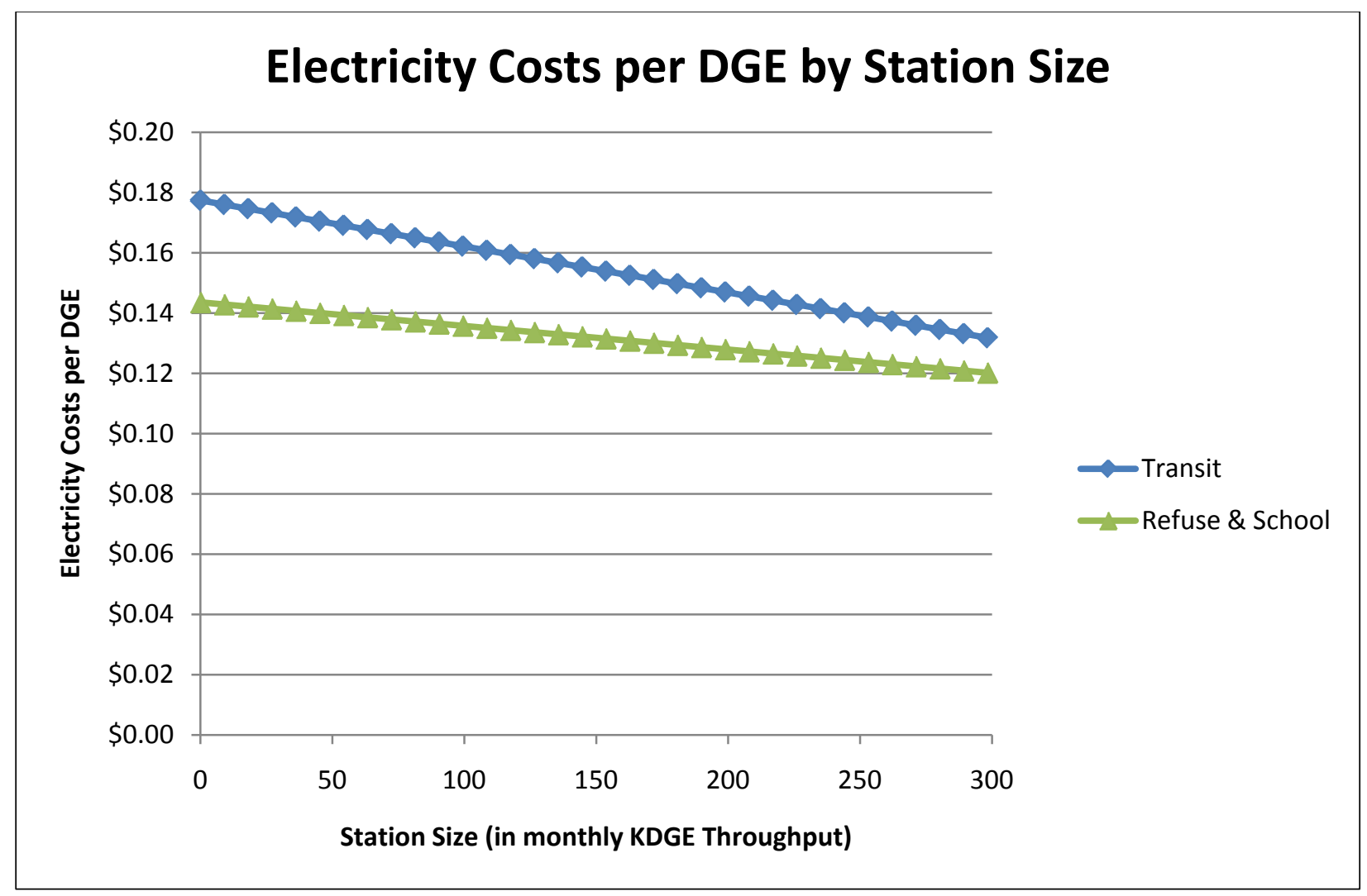

Figure 3. Electrical costs per DGE by station size

Labor for hostlers (people who refuel, clean, and maintain fleets) is not considered an additional cost in the base case because diesel vehicles need them also. Furthermore, hostlers are not an additional cost because it is generally more economical to use a hostler than to have drivers or other staff refuel the vehicles. Even though they are not included in the base case, additional hostlers will be considered in the sensitivity analysis.

\section{Fuel Price and Rate of Increase}

The VICE model's diesel fuel price of $\$ 2.563 / \mathrm{gal}$ is the average of the most recent 12 months (ending February 2010) listed by EIA (2010a). The natural gas price of \$1.183/DGE is taken as the commercial price listed by EIA (2010b) and converted from cubic feet to DGEs using EIA's conversion factor of 1,028 Btu per cubic foot. Both diesel and natural gas fuel prices are averaged over the most recent 12 months to take into account seasonal changes.

It should be noted that fleet operators frequently purchase their natural gas for less than the commercial price mentioned above. They can do this by purchasing from a gas marketer in deregulated markets, from a commodities market, or from a middle man that purchases from the market and sells a contract to provide fuel and optional services for a given amount of time. These other purchasing avenues are not used in the model because they are less common and have no common price that can be tracked and forecasted. 
Diesel fuel is projected to increase at a linear rate of $5.6 \%$ per year, and natural gas is projected to increase at $1.6 \%$ per year. These are the rates that EIA projected for the 15 years between 2010 and 2025 (EIA 2010c), as shown in Figure 4 below.

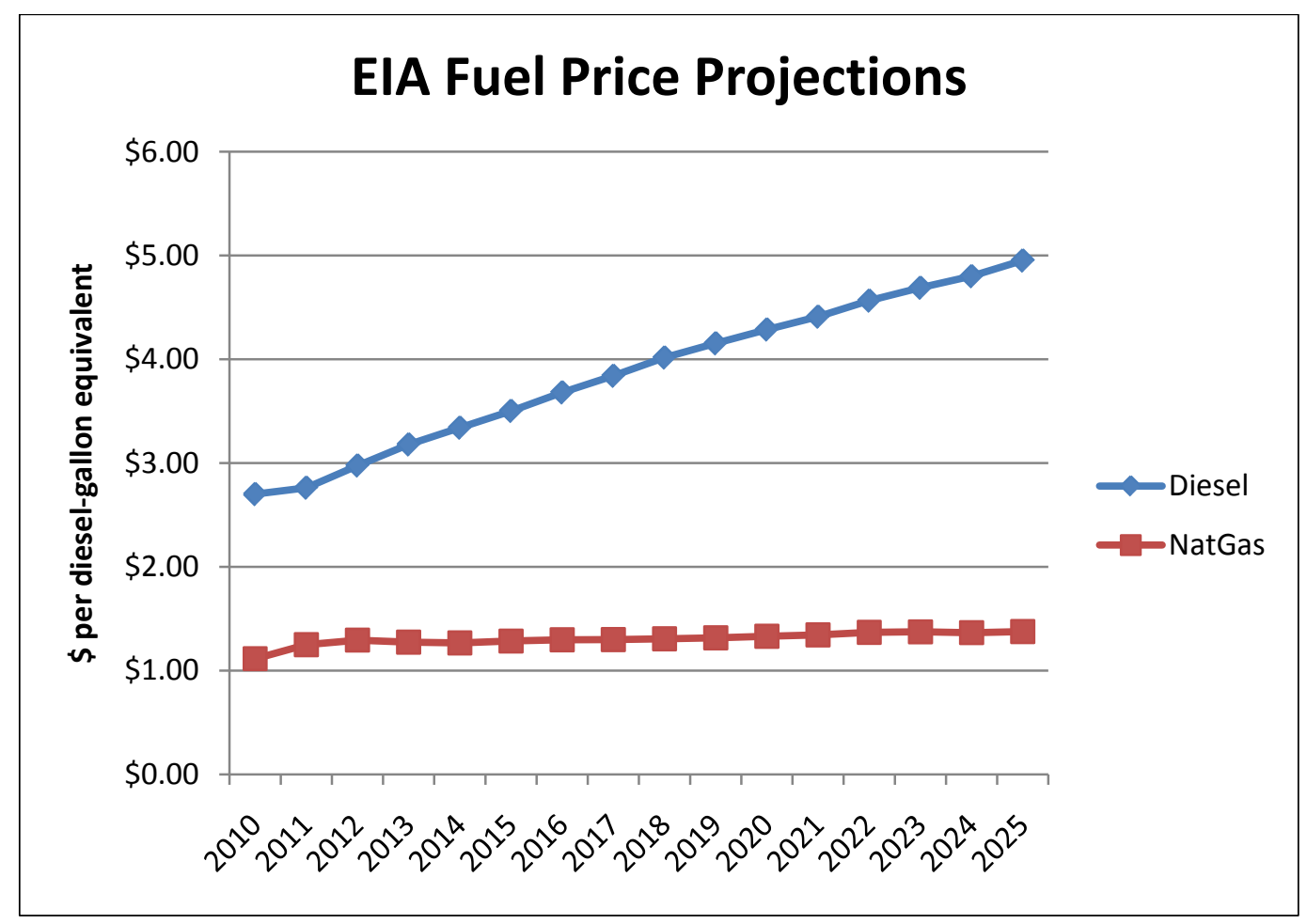

Figure 4. EIA fuel price projections

\section{Taxes and Incentives}

The federal government taxes fuel use and provides incentives for CNG use through tax credits. These credits are intended to reduce the overall cost of installing the CNG refueling station, to purchase the CNG vehicles, and to purchase CNG. The incentives have been crafted so taxexempt entities such as municipal governments can pass the credits to suppliers and therefore take advantage of the tax credits.

\section{Refueling Station}

The Alternative Fuel Infrastructure Tax Credit is available to reimburse 50\% of the cost of installing a CNG station, up to $\$ 50,000$. Tax-exempt entities are allowed to pass this credit onto the company that is building the station. The VICE baseline assumes that the builder reduces the purchase price by an amount equal to this tax credit.

\section{Vehicles}

The Alternative Motor Vehicle Credit provides a tax credit equal to $80 \%$ of the incremental cost of a CNG vehicle, to a maximum of $\$ 32,000$ per vehicle. The VICE model assumes that this tax credit is fully capitalized on by passing to the vehicle manufacturer in exchange for a lower purchase price. 


\section{Fuel}

The VICE model assumes CNG and diesel are taxed at the same level, which treats tax-exempt and non-exempt fleets the same. To do this, we had to subtract the $\$ 0.183$ federal or $\$ 0.20$ average state motor fuels excise tax on diesel or CNG fuel (IFTA 2008) from the projected retail price of diesel, which included these motor fuel taxes.

The SAFETEA-LU Act of 2005, the Tax Extenders Act of 2009, and the two NAT GAS Acts currently under consideration provide a $\$ 0.50$ motor fuels excise tax credit for each gasolinegallon equivalent (GGE) (or \$0.55 per DGE) of CNG purchased. This credit is applicable to both taxable and tax-exempt fleets through a rebate provision in the Act (NGVAmerica 2008) and is applied to both in the VICE model.

\section{Financing}

The analysis assumes that municipal governments will fund the CNG project through their annual budgets without taking a loan or issuing bonds. This assumption is supported by the experience of a number of Clean Cities coordinators whereby an ordinance was passed one year and the funds allocated for a CNG project the following fiscal year.

When looking at the payback period and net present value (NPV) of a CNG project, we need to consider the discount rate. The discount rate is considered 6\% - the upper limit for a key municipal bond index since 1997 (WM Financial 2009). This rate is assumed because it is the upper end of the cost of capital for municipal governments.

\section{Garage Cost}

The facility upgrade costs associated with upgrading a fleet from diesel to CNG are considered zero. This is in agreement with the fact that the incremental cost of making a new garage and maintenance facility compatible with CNG is minimal (Marathon 2006). Therefore, the model implicitly assumes the fleet already has well-ventilated facilities or that they are building new facilities that would be the same cost regardless of fuel type. However, garage upgrade costs will be modeled in part two of this analysis to explore their effects on the economics of a CNG project.

\section{Project Life and Salvage Value}

The project life, or investment period, is the same duration as the vehicle's useful life. As discussed above, this is 15 years for transit and school buses, 12 years for refuse trucks, and 14 years for any fleet that combines refuse trucks with buses.

The station is assumed to be used throughout the entire project period (vehicle life) and then salvaged at the end of that period. The salvage value of the station is assumed to be $20 \%$ regardless of how many years $(12,14$, or 15$)$ it has been in service. This number is static throughout time because the value is more a function of demand for components than it is the age of the components. The $20 \%$ value was chosen after interviewing two CNG station technicians that have overseen dozens of projects.

The difference between diesel and CNG salvage values of all three vehicle types is considered zero (Linder 2009 and Lemmons 2009). This means that at the end of the vehicle's life, a CNG vehicle is worth no more than a diesel vehicle. 


\section{CNG Project Q\&A}

The base case represents an average or common $\mathrm{CNG}$ project. Every project deviates from this base case, which is why fleet operators question the specific parameters of their projects. The questions and answers in this section are organized to first give fleet managers their bearings and show how profitable the base-case project is. The following questions go on to address changes in fuel expenditures, changes in operating costs, and changes in upfront costs.

\section{How do I know if a CNG project makes financial sense?}

Most investors use three indicators of financial viability, which all stem from a discounted cashflow analysis performed by models such as the VICE model. These indicators are:

1. Net Present Value (NPV). This is the total present value of a CNG project, including the cost of CNG equipment purchased now along with future costs and cost savings from fuel and operations throughout the lifetime of the project. These costs and cost savings are called "cash flow," with costs being a negative cash flow and savings being a positive cash flow. Please see the baseline parameters section (pp. 1-9) for all cash flows that are included in the VICE model. All future cash flows are discounted at a "discount rate" to compensate for the fact that money is worth more today than it is in the future because it can be invested today and increased. If the NPV of the project is positive or zero at the desired discount rate, the project makes financial sense. The NPV of the hypothetical investment in Figure 5 is $\$ 7.2$ million, where cumulative cash flows stop increasing at the end of the project life.

2. Rate of Return (ROR). The ROR is the desired annual return on investment. When choosing a target ROR, many companies compare it to what they could make if they invested their money in another project with similar risk. Ten percent is often considered a good baseline in the private sector because that is what the stock market has averaged over the long term. In municipal governments, $6 \%$ is generally considered the baseline because that is what it costs a government to raise money through bonds. ROR is also the discount rate on money if one sets the NPV to equal zero.

3. Payback Period. This lets an investor know when the investment has broken even and is starting to turn profits. At this point, an investment no longer carries the risk of losing money. When assessing the payback period, the investor uses the same discount rate as used when looking at the NPV. In Figure 5, it takes the fleet manager 4 years to pay back the initial investment of $\$ 2.6$ million. Stable, progressive fleets can have a target payback of 7 years while more risk-adverse fleets can require a 3-year payback. The payback period seems to be the metric of choice for fleet managers despite its drawback of not being able to quantify losses on a bad investment. 


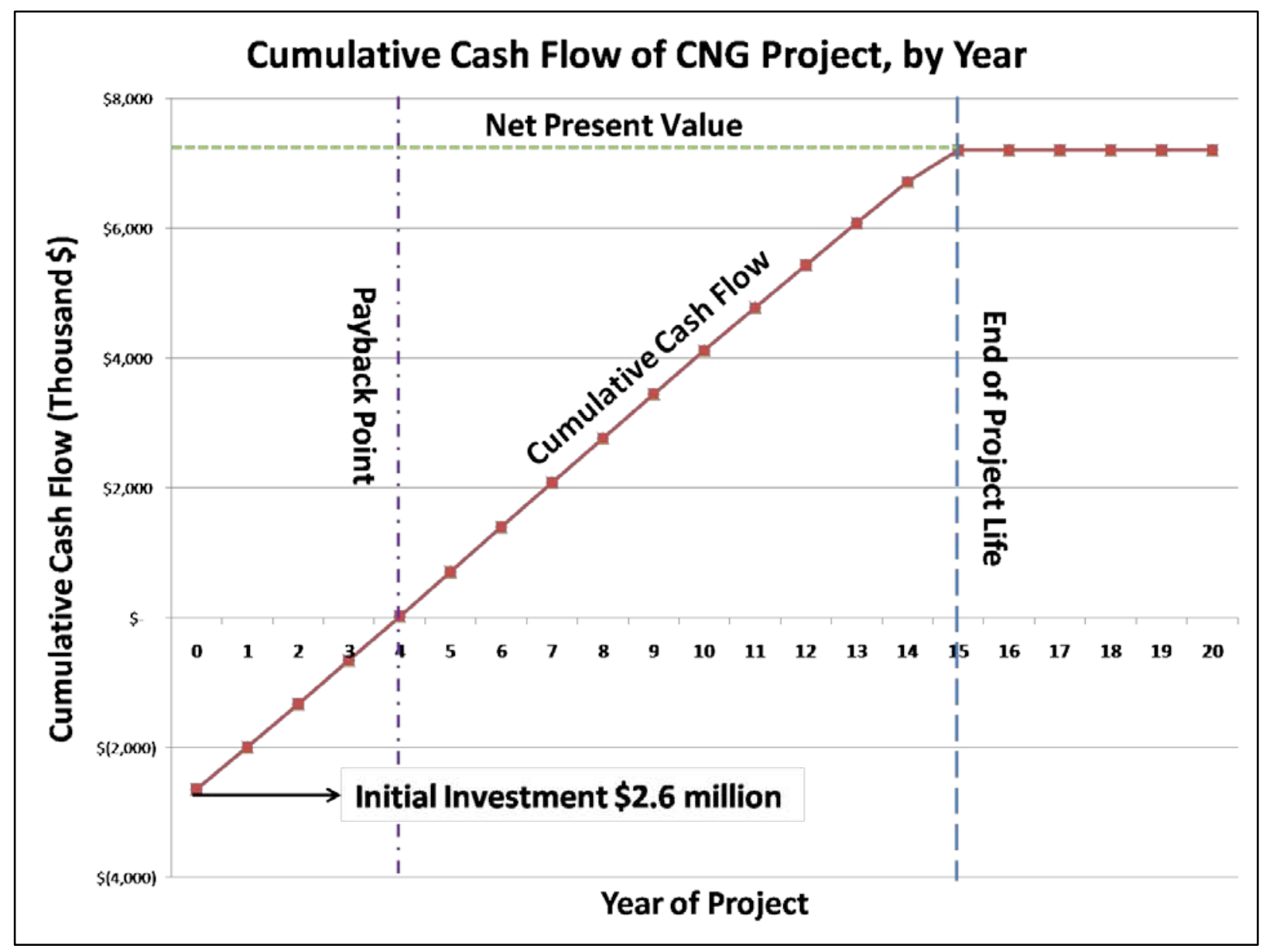

Figure 5. Cumulative cash flow of an example CNG project, by year

\section{Base-Case Results}

This section answers three questions about the base-case results.

\section{What will my payback period be?}

NREL ran the VICE model under a base-case or most-probable scenario for a transit fleet, school fleet, and refuse fleet (as described in Section 1). The results of this run show that the payback periods depend largely on fleet size and fleet type (Figure 6). Transit and refuse projects have a precipitous drop in payback period at around 30 vehicles. Any fleet larger than this will have a payback period of less than 7 years.

School bus fleets need to be larger than the other two fleets for a given payback period because each school bus uses less fuel. A fleet of 250 school buses pays back in about 7 years, but there is no clear dropoff the way there is for the other two fleets. Please note that the maximum payback period for a refuse truck is 12 years because that is the average life of these trucks while transit buses and school buses have an expected 15-year life. 


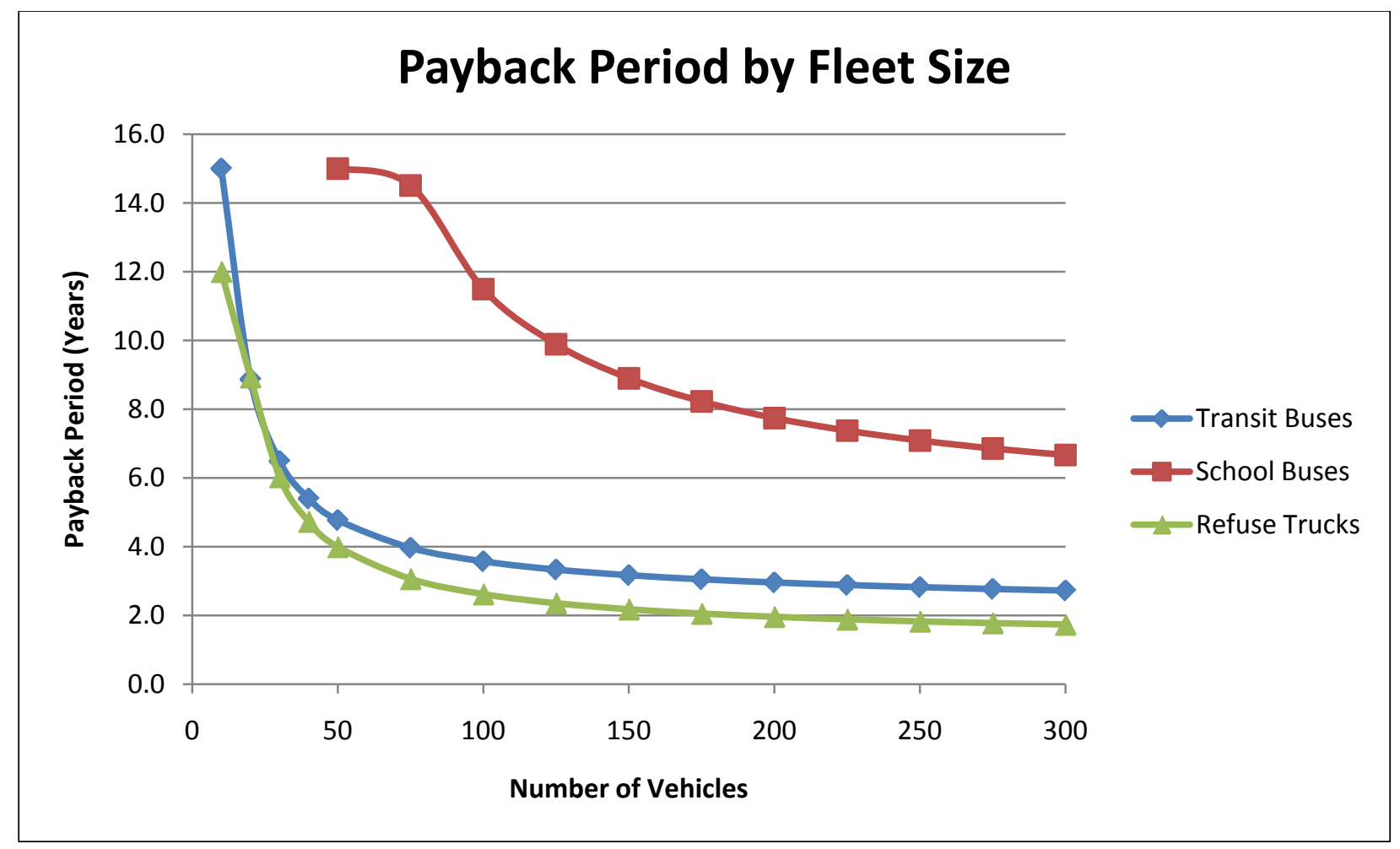

Figure 6. Payback period by fleet size

\section{What will my ROR be?}

Base-case refuse and transit projects look very profitable when judged on the basis of ROR. With fleets as small as 25 buses, they can provide returns that are deemed acceptable by any organization, and large fleets yield extraordinary returns. Refuse projects become more profitable than transit projects as the fleet size increases - probably because the larger refueling window allows increased vehicle usage without increasing fueling capacity.

School bus projects require large fleets to provide a good ROR. The ROR surpasses $6 \%$ with a 75 -vehicle fleet and $10 \%$ with a 100 -vehicle fleet. It then maxes out at $21 \%$ ROR, which is quite a good investment for a municipal government. 


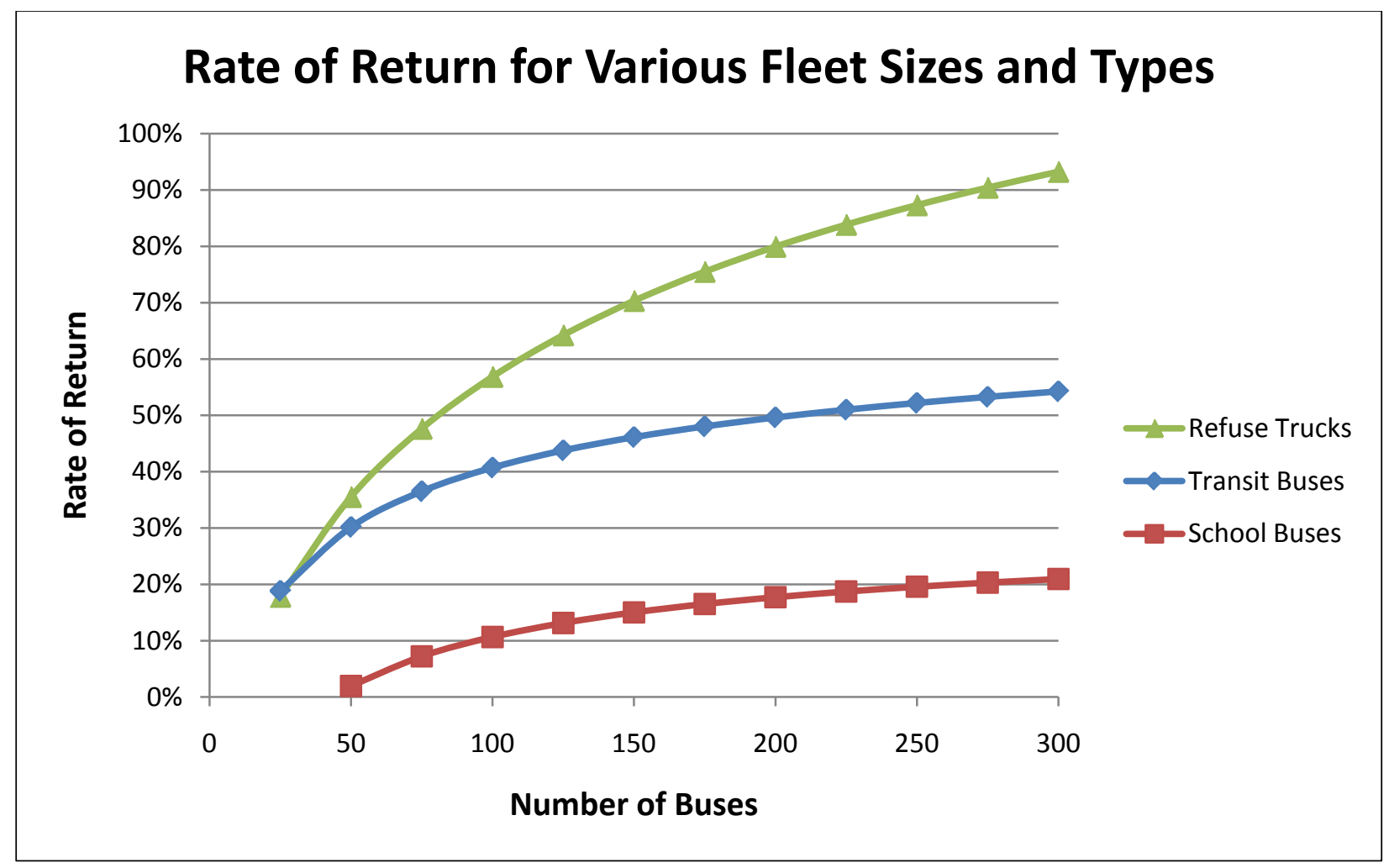

Figure 7. Rate of return for various fleet sizes and types

\section{What is the NPV of my investment?}

Transit buses are the best fleets to convert when judged by the NPV metric because they use more fuel than the other fleets, which results in greater fuel savings by the end of the project's life. The reason why transit fleets are more profitable than refuse fleets when looking at NPV but less profitable when looking at ROR is that they require a larger upfront investment. As shown in Figure 8, a 300-transit-bus fleet, which requires an initial investment of $\$ 11.8$ million, has an NPV of $\$ 55$ million. The NPV for transit fleets turns positive at 11 buses, for refuse fleets at 14 trucks, and at 68 school buses. 


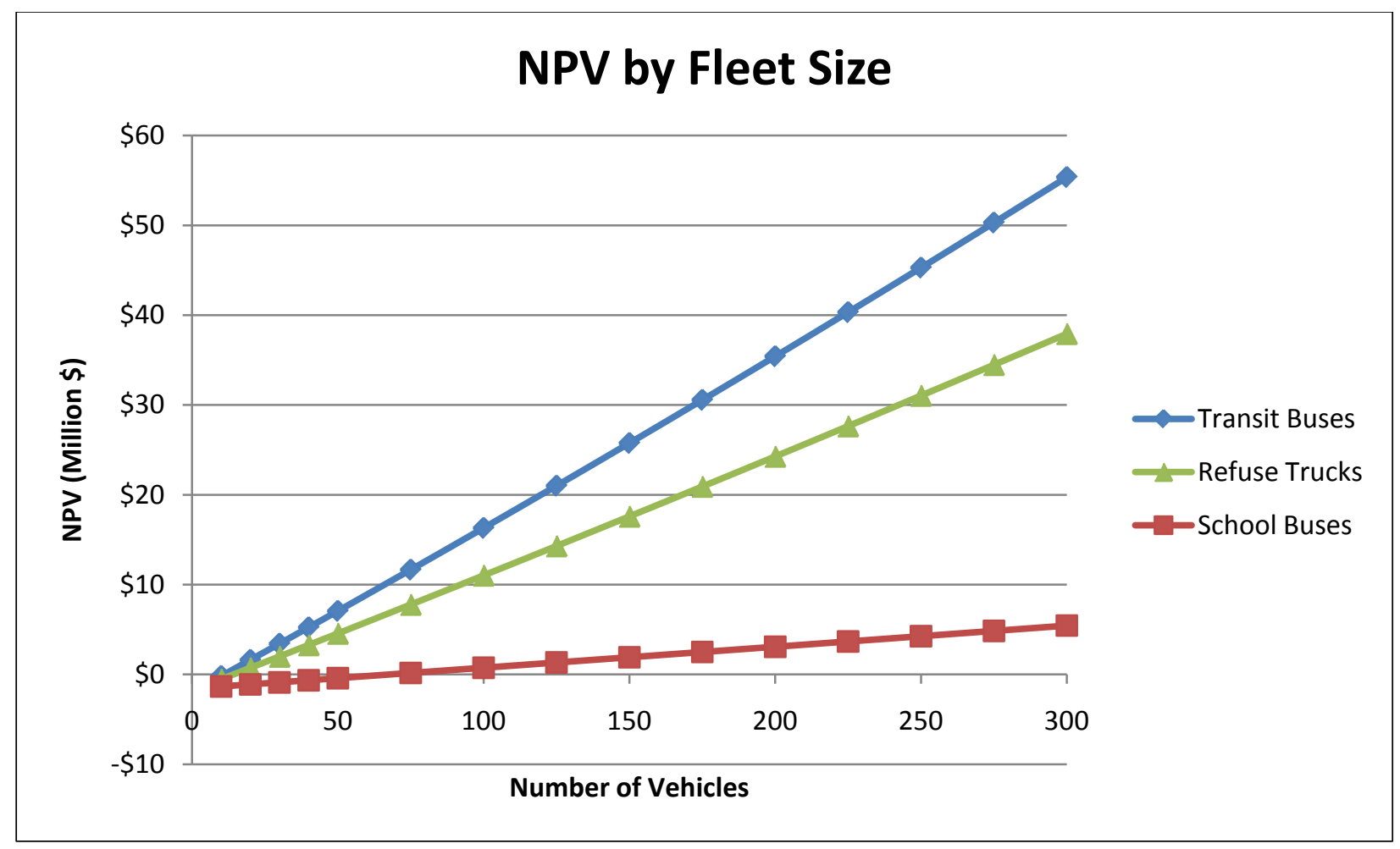

Figure 8. Net present value by fleet size

\section{What is the minimum number of vehicles required to break even?}

The minimum goal of an investor is to break even when taking into account the cost of tying his money up for the life of the project. This is the point in Figure 8 where the NPV of a project crosses from negative to positive, and it is also the point in Figure 7 where the ROR reaches $6 \%$ (the discount rate for municipal governments). Table 2 summarizes the minimum number of vehicles to break even for the three main municipal fleets and various combinations where vehicles of different types share municipal infrastructure.

Table 2. Minimum Number of Vehicles to Have a Positive NPV or $6 \%$ ROR

\begin{tabular}{|l|r|}
\hline Type of Vehicle & \# of Vehicles \\
\hline Transit Buses & 11 \\
\hline School Buses & 68 \\
\hline Refuse Trucks & 14 \\
\hline $1 / 2$ Transit, 1/2 School & 26 \\
\hline $1 / 2$ Transit, 1/2 Refuse & 12 \\
\hline $1 / 2$ School, 1/2 Refuse & 32 \\
\hline $1 / 3$ Each & 22 \\
\hline
\end{tabular}

\section{Variations in Fuel Expenditures}

The base case has already shown that project profitability is very dependent on fleet size. This is one factor affecting the fuel expenditures of a project. Fuel expenditures are very influential on project profitability because upfront costs are largely paid for by a reduction in CNG 
expenditures below those of diesel. Therefore, to achieve maximum benefit from the use of $\mathrm{CNG}$, negotiating and securing low long-term natural gas prices is critical. Other questions that explore fuel expenditures follow.

\section{How many miles per year do I need to drive my vehicles to break even?}

Fuel costs are dependent on both the price of the fuel and the number of miles driven by the fleet. Because natural gas is generally less expensive than diesel, the greater the number of miles a vehicle drives, the more savings a fleet will see compared to conventional fuel. Figure 9 shows the relationship between average VMT and the number of vehicles needed to pay off a CNG investment. The area above the curve is profitable for the fleet, and the area below the curve is not profitable.

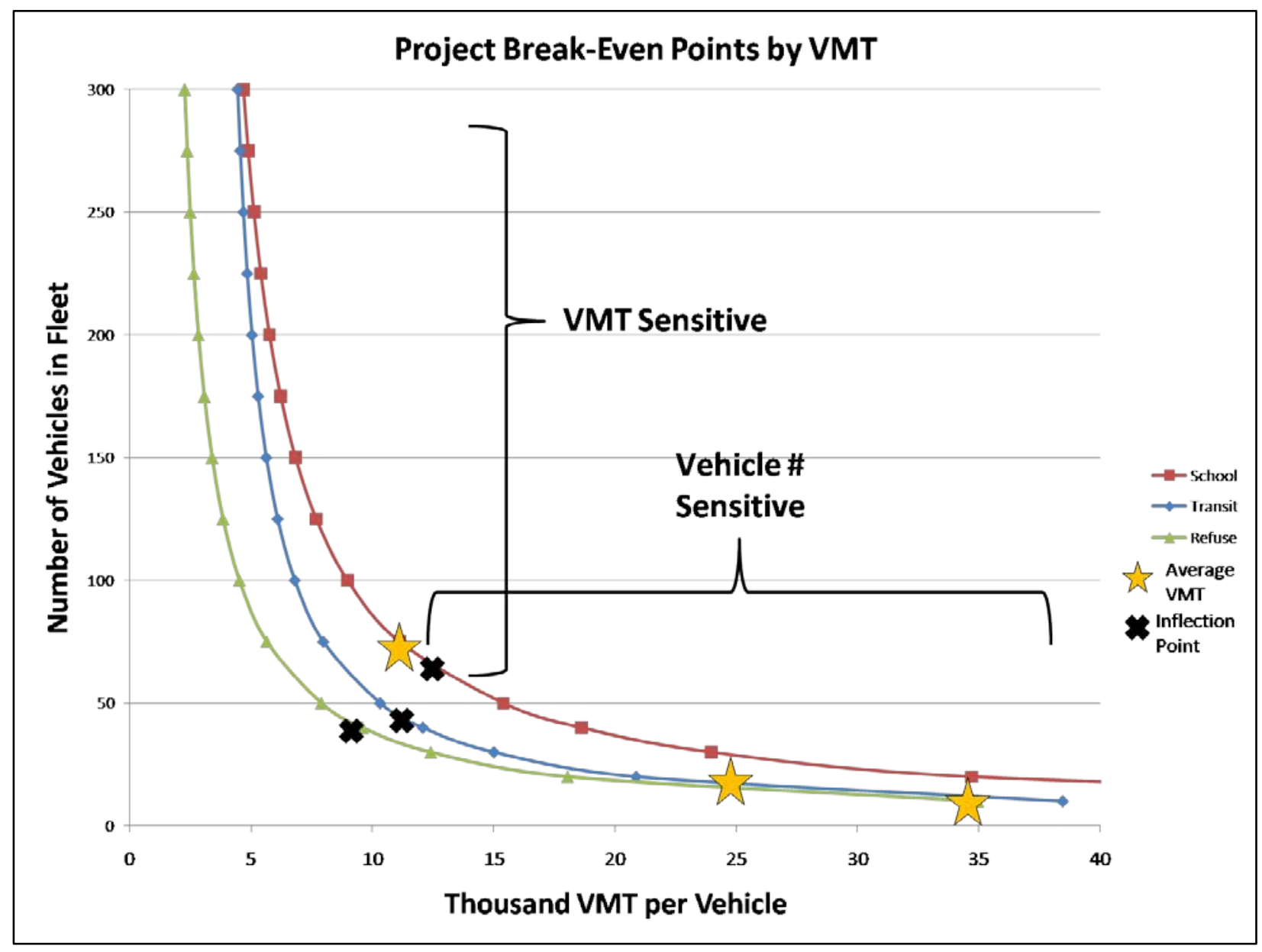

Figure 9. Project break-even points by VMT

The most noteworthy part about Figure 9 is how steep the transit and refuse fleet lines drop between 2,500 and 10,000 VMT and how flat they are after 10,000 VMT. The point of transition is labeled as the inflection point. The inflection of the school bus fleet is less pronounced than the other two but still there. The profitability of any point above the inflection point is more sensitive to the VMT changes, and any point to the right of the inflection point is more sensitive to changes in the number of vehicles. Given where the average VMTs of transit and refuse fleets 
fall, their economics are much more sensitive to their vehicle number than VMT. Average school fleets are barely above the inflection point, so they should be only slightly more concerned with their VMT than the number of vehicles when considering a CNG project. Keep in mind that any VMT-vehicle combination to the right or above the curves is considered a profitable project.

\section{What will a change in diesel prices do to my payback period?}

Diesel prices are highly variable. Over the past two years, they have varied 0.8 standard deviations from the mean, as opposed to 0.2 for CNG (Laughlin 2010). Therefore, it is very important to find out what effect a change in diesel price will have on project economics. To answer this question, NREL compared the baseline price of natural gas at \$1.18/DGE against different diesel prices. Both CNG and diesel were set to increase 3\% per year to keep up with inflation. The effect that diesel price has on payback period is shown in Figure 10 for the three municipal fleets at 50 and 100 vehicles each.

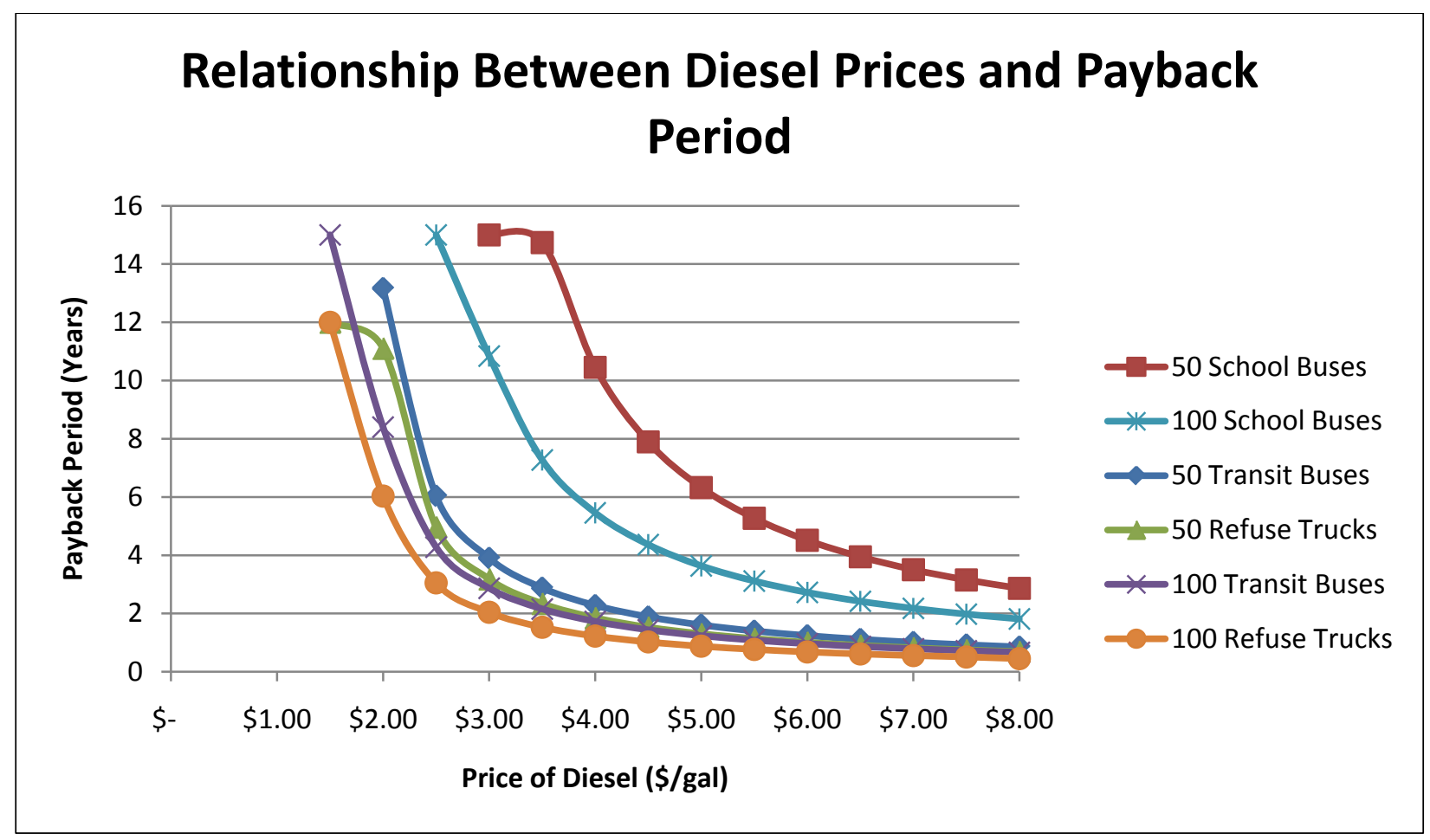

Figure 10. Relationship between diesel prices and payback period

Figure 10 reiterates that the economics for a school bus fleet under the base-case scenario are very dependent on the size of the fleet. A school bus project appears to achieve only a reasonable payback once diesel prices approach $\$ 4 /$ gallon for 100 -bus fleets and $\$ 5 /$ gal for 50 -bus fleets.

The main observations when considering fluctuating diesel prices (shown in Figure 10) for refuse and transit fleets are: 
1. Project economics look strong for transit and refuse fleets of either size if the price of diesel is $\$ 2.50$ or greater. This responds to a payback period between 3 and 6 years, depending on fleet type and size.

2. As the price of diesel increases past $\$ 2.50$, the size and fleet type (transit or refuse) become increasingly irrelevant. For prices below $\$ 2.50$, larger fleets are favored, and refuse fleets are favored over transit.

3. Recent diesel price of $\$ 2.56$ is on the inflection point of this graph. If diesel prices rise, project economics look very good, and if they fall to $\$ 2.00$, they do not look very good.

\section{What does the composition of my fleet do to my project economics?}

Some municipal governments have a unique capability to fuel multiple fleets/vehicle types from one CNG station. This offers the primary advantage of staggering refueling times and expanding the station's refueling window because different fleet types can refuel at different times of the day. NREL modeled combination fleets by taking the weighted average of the vehicle attributes such as VMT, fuel economy, efficiency penalty, and incremental cost. NREL then assumed these fleets would use a refuse-style CNG station because of its 12-hour refueling window and ability to be scaled up in a cost-efficient manner. Multi-purpose fleets used the transit fleet electricity cost assumptions if there were any transit buses involved (because they raise the capacity charges), and non-transit combinations used the refuse-school electricity charge assumptions. The payback periods for these combined fleets are shown in figure 11 .

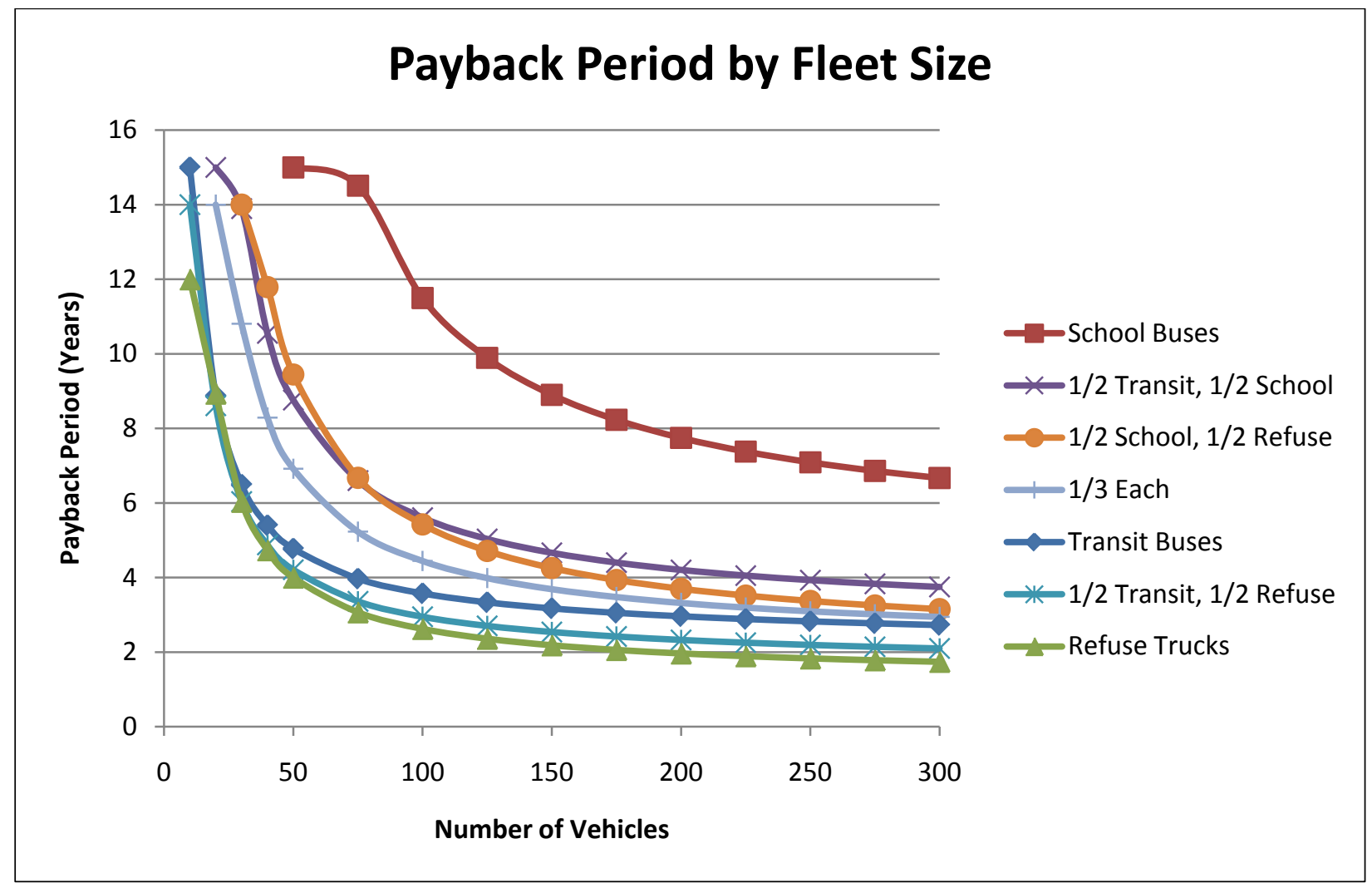

Figure 11. Payback period by fleet size for main and combination fleets 
The most conspicuous feature of Figure 11 is how much a school bus fleet's economics improve by combining with a transit or refuse fleet. The payback for a fleet of 100 is 2.9 years if a school has combined with a refuse fleet, compared to 11.5 years if they don't combine.

A second important point to be learned from Figure 11 is that the combined fleets' payback periods are always less than the midpoint between the two fleets. This means that combining the fleets tends to capitalize on the relative economic advantages of each fleet while minimizing each fleet's disadvantages. This advantage holds for the fleet that combines all three vehicle types and has payback periods well below the weighted average of the three individual fleets.

\section{What happens as my vehicle efficiency changes?}

CNG vehicles are generally less efficient than diesel vehicles when compared on a BTU (or DGE) basis. However, this drop in efficiency varies widely, depending on the specific engines and vehicles being compared. Furthermore, this drop is being reduced as CNG technology improves and as diesel engines strive to comply with new emissions standards. It is plausible, but unlikely, that some fleets could compare vehicles where the $\mathrm{CNG}$ vehicle is more efficient than its diesel counterpart.

To test the effect of this efficiency change in CNG fleets, NREL ran the VICE model with varying assumptions in the diesel-to-CNG efficiency change. The results are shown in Figure 12, where a negative efficiency change means that the CNG vehicle is less efficient than the diesel vehicle. This efficiency change was found to not have much effect on the transit and refuse fleets - on average, a 10\% improvement in relative efficiency reduced the payback period by 0.43 years. Efficiency change had more of an effect on 100 -school bus fleets, where a $10 \%$ increase in efficiency subtracted 1.2 years off the payback period. The change had no effect on 50 -school bus fleets because none of them had a payback period of less than the project life.

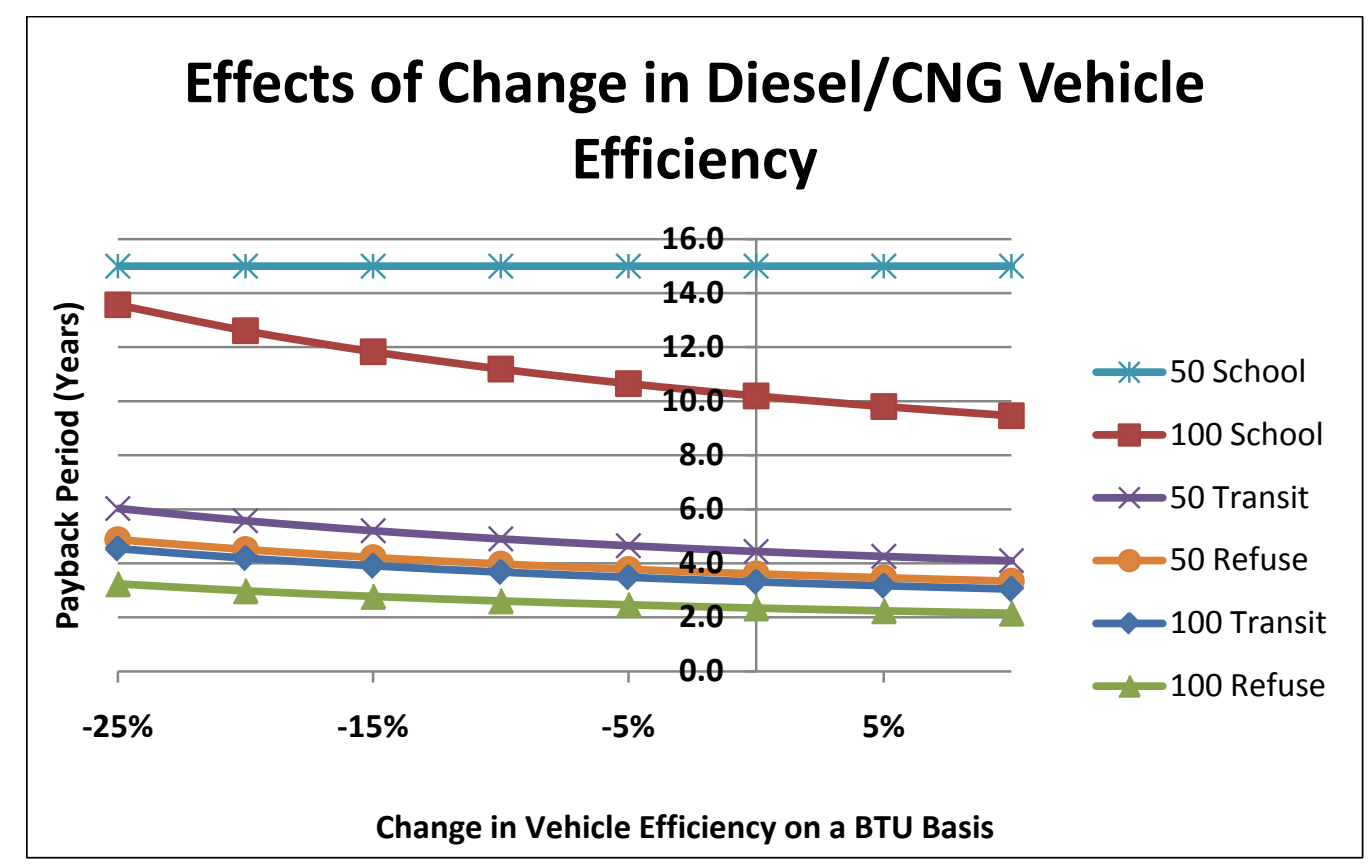

Figure 12. Effects of a change in diesel/CNG vehicle efficiency 


\section{What if the $\$ 0.55 / D G E, 80 \%$ vehicle incremental cost, or $\$ 50,000$ station tax credit is taken away or not passed along?}

The base case takes into account government subsidies that encourage the use of CNG. These include a $\$ 0.50$ credit for every GGE ( $\$ 0.55$ per DGE) purchased, a credit to cover $80 \%$ of the incremental cost of a CNG vehicle, and a credit of $\$ 50,000$ for installing a CNG station. These are tax credits that, as discussed in the model parameters section of this report, are supposed to be made accessible to tax-exempt entities through certificates and pass-alongs. However, they are often not made available to the fleet. Table 3 shows what happens if these credits are not made available.

Table 3. Payback Period (Years) with Various Tax Credits Missing

\begin{tabular}{|l|r|r|r|r|r|}
\hline $\begin{array}{c}\text { Fleet }(100 \\
\text { Vehicles) }\end{array}$ & All Credits & \multicolumn{1}{c|}{$\begin{array}{c}\text { No Fuel } \\
\text { Credit }\end{array}$} & \multicolumn{1}{c|}{$\begin{array}{c}\text { No Vehicle } \\
\text { Credit }\end{array}$} & \multicolumn{1}{c|}{$\begin{array}{c}\text { No Station } \\
\text { Credit }\end{array}$} & \multicolumn{1}{c|}{$\begin{array}{c}\text { No } \\
\text { Credits }\end{array}$} \\
\hline Transit Buses & 3.6 & 5.9 & 5.5 & 3.6 & 9.1 \\
\hline School Buses & 11.5 & $\geq 15.0$ & $\geq 15.0$ & 11.8 & $\geq 15.0$ \\
\hline Refuse Trucks & 2.6 & 4.6 & 4.8 & 2.7 & 7.8 \\
\hline
\end{tabular}

Note that taking away the two tax credits from the transit (or refuse) scenario only increases payback period $4.2(2.3+1.9+0.0)$ years independently, yet they increase 5.5 years combined. Therefore, there are synergies between the three tax credits that result in additional benefits, making it important to consider the relationships between tax incentives when evaluating the benefits of them. It is also important to note that taking either one of the first two tax credits away makes school projects not pay off.

\section{What if I have to pay fuel excise taxes on diesel but not CNG?}

The base case assumes that a fleet pays the same excise tax on diesel as on CNG. However, this is not always the case. Fleets might refuel at various private diesel stations where they have to pay excise taxes while their future CNG station would be tax-free. There are also cases where a tax-paying entity (such as a contractor) gets state tax breaks for CNG but not diesel. Table 4 shows how this lopsided taxation decreases the payback period for CNG projects by over $20 \%$ for all three fleets.

Table 4. Payback Period for 100 -Vehicle Fleet

\begin{tabular}{|c|r|r|r|}
\hline Fleet Type & Both Fuels Exempt & Only CNG Exempt & \% Reduction \\
\hline Transit Buses & 3.6 years & 2.8 years & $22 \%$ \\
\hline School Buses & 11.5 years & 9.0 years & $22 \%$ \\
\hline Refuse Trucks & 2.6 years & 2.0 years & $23 \%$ \\
\hline
\end{tabular}

\section{How does vehicle life affect my project economics?}

The VICE model sets project duration to the same length as vehicle life, so a change in vehicle life essentially influences how much fuel is used over the course of a project. The model found, however, that a change in vehicle life had only a small effect on project profitability. As vehicle life changed from 10 years to 20 years, the ROR for 50 -vehicle transit and refuse fleets increased less than 4\%. A 50-vehicle school fleet showed the greatest improvement with an $11 \%$ increase in ROR over the same range of vehicle life. 


\section{Changes in Upfront Costs}

Many profitability questions focus on upfront costs because these are the costs that need to be paid back for the ROI, NPV, or payback period to be acceptable to the fleet manager.

\section{What happens if the price of my station changes?}

Station prices vary widely depending on location, specific fleet requirements, lot characteristics, and many other factors. To test the effect of this variation on project economics, NREL modeled three CNG projects with baseline cost, baseline $+50 \%$, and baseline $-50 \%$. The school and refuse stations are shown in Figure 13; transit is not shown because it was so similar to refuse that it obscured the curves.

Figure 13 reveals the effects of changing the station cost, such as:

- The influences of increasing/decreasing 50\% are symmetrical. Increasing the station cost $50 \%$ has an equal and opposite effect on payback years as decreasing it $50 \%$.

- The school bus fleet is much more sensitive to changes in station cost than the other fleets. A $50 \%$ reduction in cost reduces payback by 4.9 years in a 75 -bus fleet and 1.7 years in a 300-bus fleet.

- In the refuse fleet, a $50 \%$ reduction in cost reduces the payback period by less than a year if the fleet is over 100 buses. It can make up to a 4-year difference in very small (20truck) fleets.

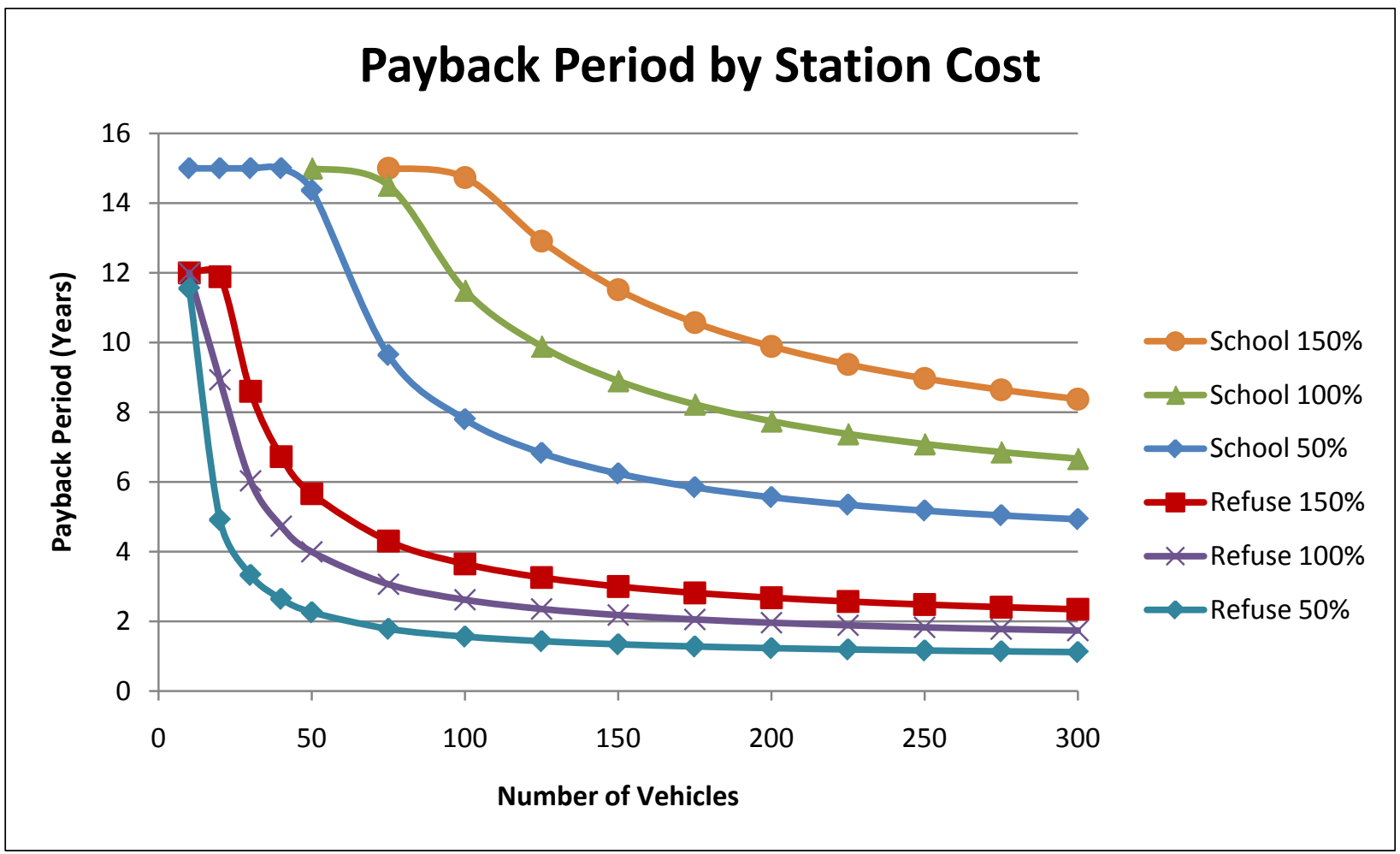

Figure 13. Payback period by station cost 


\section{What happens as my vehicle incremental cost changes?}

There is a distinct possibility that manufacturing efficiencies will decrease the cost of a CNG vehicle or that 2010 emissions requirements will increase the cost of a diesel vehicle. Either of these events would reduce the incremental cost of a CNG vehicle (over a diesel vehicle). There is also a possibility that the $\mathrm{CNG}$ vehicle purchased by your fleet has a higher incremental cost than the averages used in the base case. To explore the impact of these scenarios on project profitability, NREL modeled one case where the incremental cost of a CNG vehicle is zero, one scenario where it is at the baseline, and one where it is double the baseline. The results are shown in Figure 14.

For both fleets shown in Figure 14, the base-case line is much closer to the zero-incremental-cost line than it is to the double-incremental-cost line. This is largely due to the fact that incremental costs are displaced by the tax incentive up to approximately the base incremental cost. Beyond the base incremental cost, the government's incentive helps very little because it caps out when the incremental cost is greater than $\$ 40,000$.

The doubling of incremental costs is particularly damaging to the school bus fleet for two reasons. Foremost, each bus uses less fuel over its lifetime, so there is less opportunity for fuel cost savings to make up for this cost. Secondly, the baseline incremental cost is slightly more expensive for a school bus than for a refuse hauler.

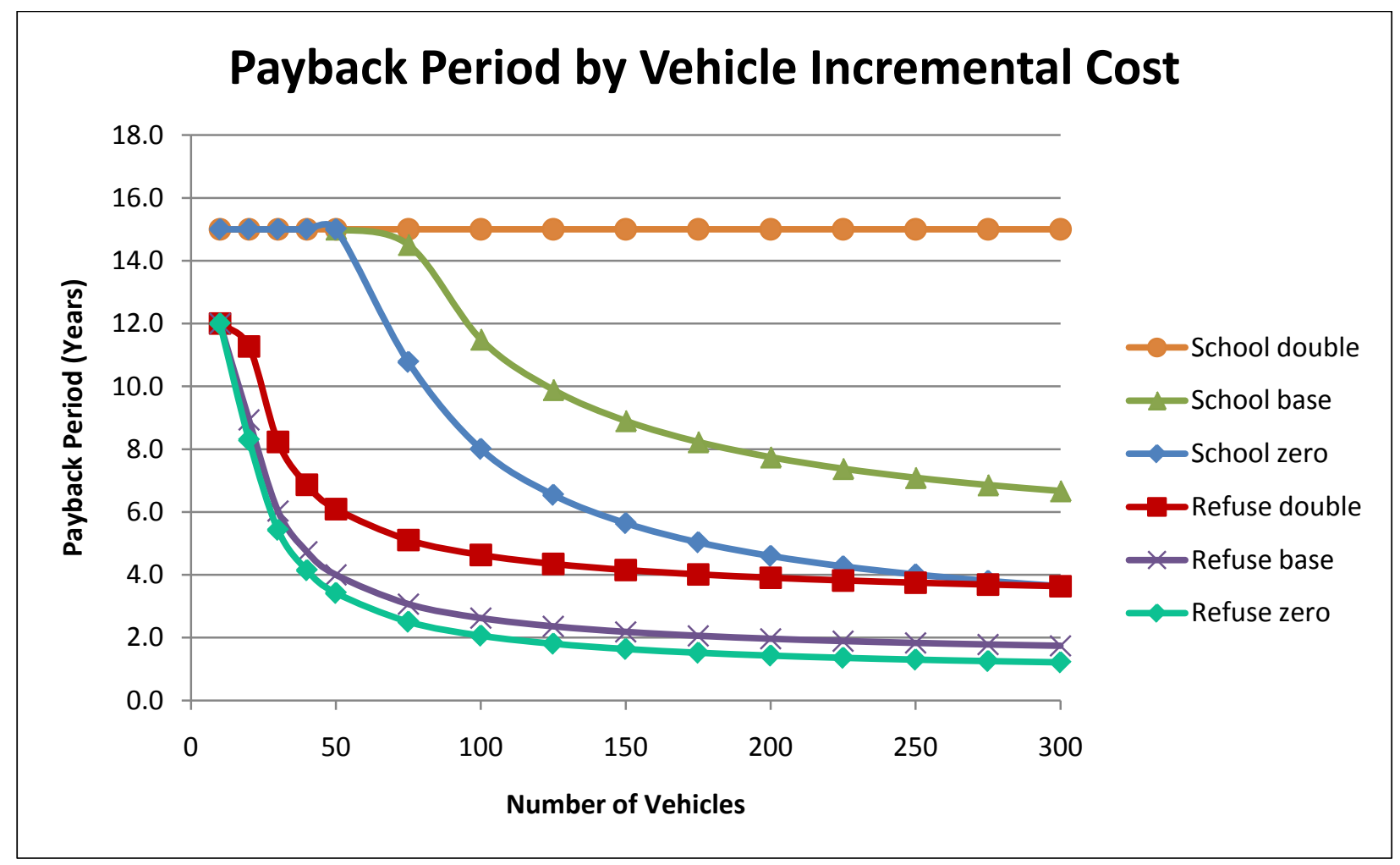

Figure 14. Payback period by vehicle incremental cost 


\section{What if I receive a grant from the Federal Transit Administration?}

The Federal Transit Administration (FTA) offered grants for transit buses in urban areas through its Urbanized Area Formula Program and Clean Fuels Grant Program. The funding for these programs has recently expired but is expected to resume through upcoming legislation. The grants are expected to pay for $80 \%$ of the cost of a diesel bus and $83 \%$ of the cost of a CNG bus to those eligible recipients. This funding scenario results in the CNG buses actually being $\$ 2,700$ less than the diesel buses in the VICE model. FTA grants nullify the previously mentioned vehicle tax credit, so those were not factored into the cost. When this scenario was modeled, it reduced the payback period for transit buses by approximately 1.6 years for all fleet sizes over 10 vehicles, as shown in Figure 15.

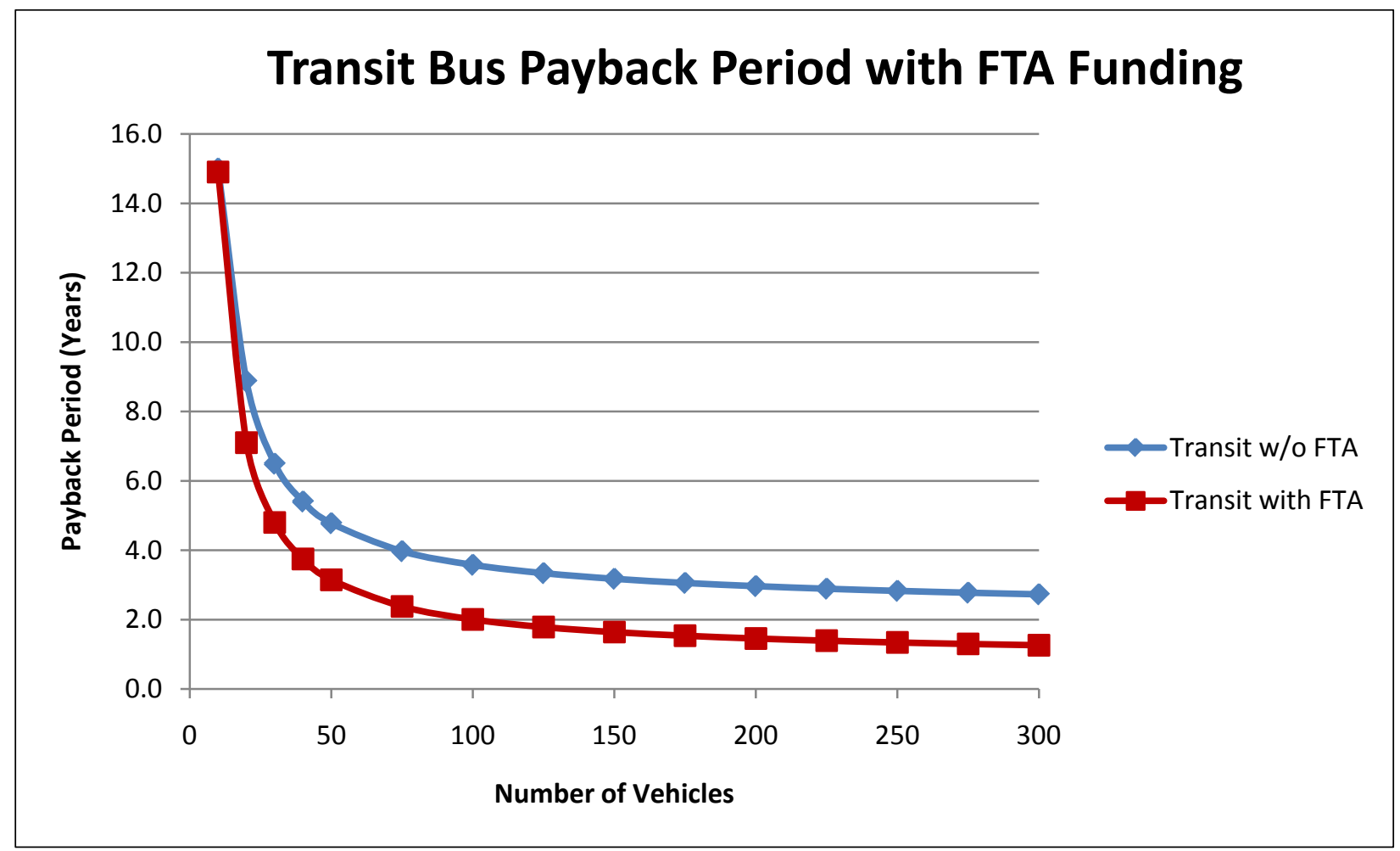

Figure 15. Payback period of a transit bus with and without FTA funding

\section{What happens as I have more or less time to refuel?}

A fleet's refueling window (the time in which vehicles are available to refuel) increases if the fleet's schedule is more relaxed or staggered. This staggering usually increases as the station's fleet is diversified by serving different types of vehicles or by opening to the public.

To test the impact of an increased refueling window, NREL ran the VICE model with identical fleets of refuse trucks being refueled by stations with a 6-hour and 12-hour refueling window. The stations were automatically sized, equipped, and priced to accommodate their respective refueling windows. As shown in Figure 16, the CNG project with the 12-hour refueling window provided an increasingly larger ROR as the fleet size increased. 


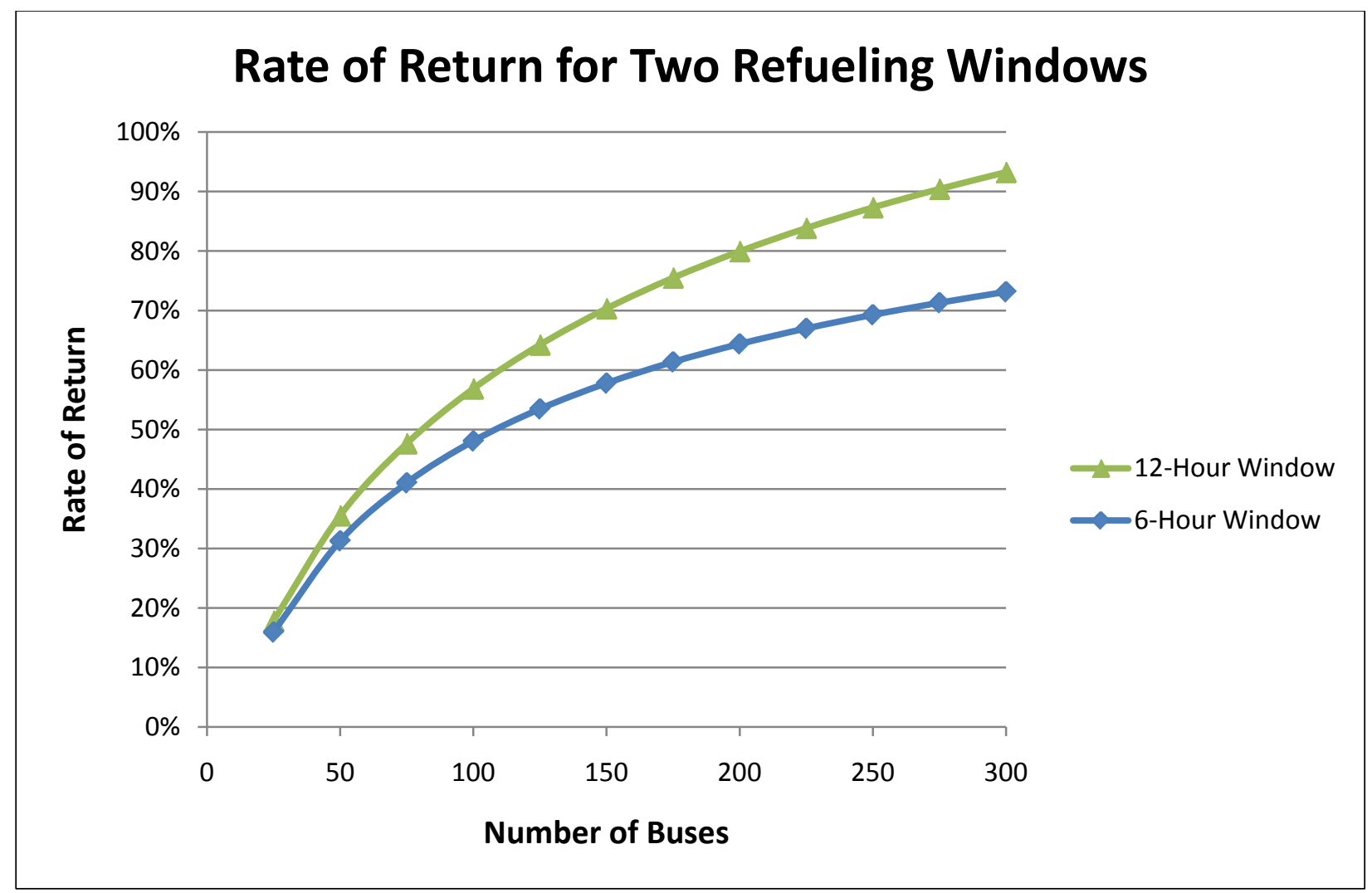

Figure 16. Rate of return for a 6-hour and 12-hour refueling window

\section{What if I have to upgrade my garage?}

Some garages are not equipped to store $\mathrm{CNG}$ vehicles. Upgrades to the garage are part of the upfront costs for the fleet, such as infrastructure. The cost to retrofit a garage varies widely, as explained by Adams (2006). In one scenario, a garage required a gas-detection system that cost $\$ 3,750$ per bus plus $\$ 40,000$ for a control panel. The VICE model indicated this garage cost had no significant impact on transit and refuse fleets. However, it increased the payback time to school fleets 1.8 years to 2.3 years depending on the size of the fleet. 


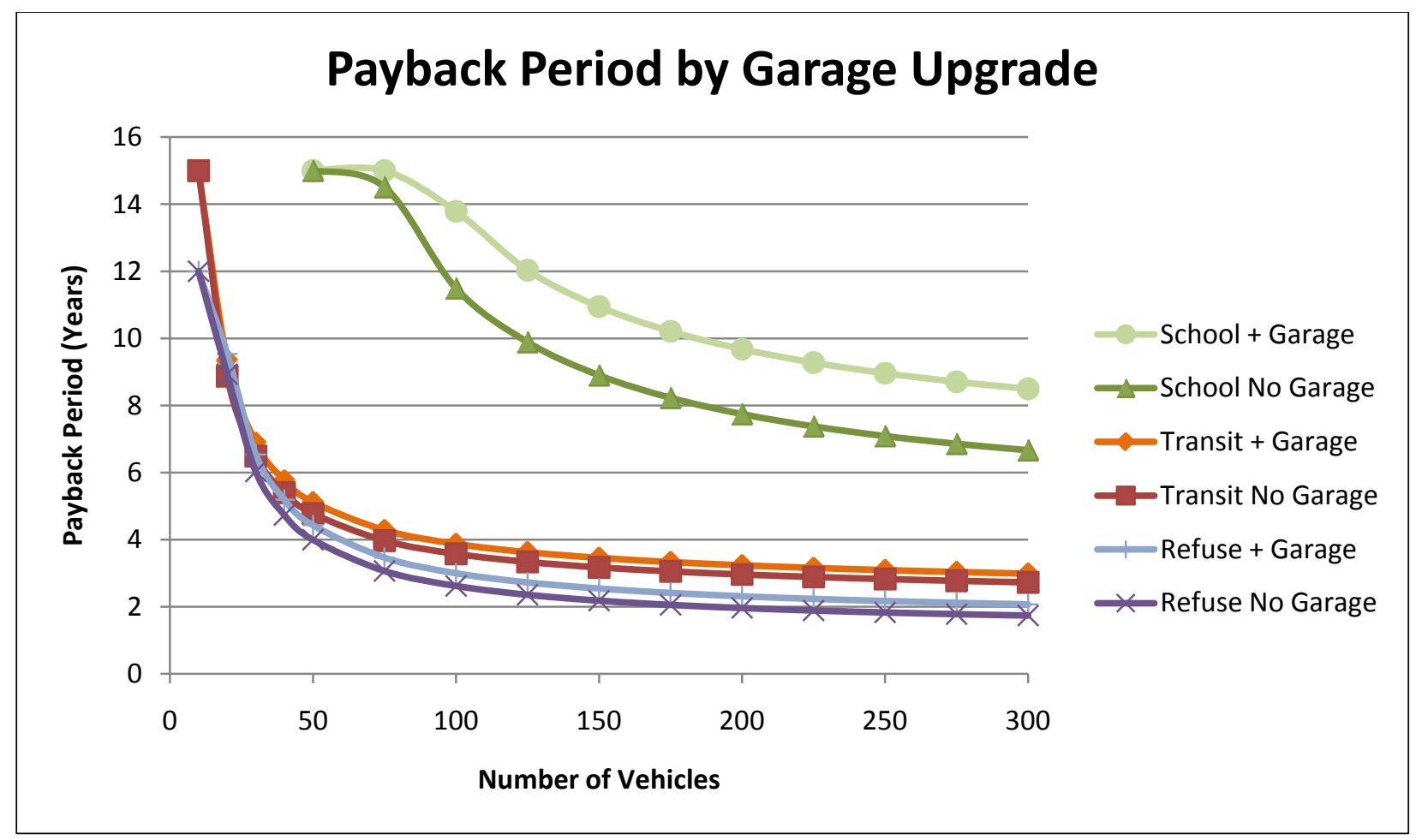

Figure 17. Payback period by garage upgrade

\section{Changes in Operating Costs}

\section{What happens if my vehicle maintenance costs change?}

Switching to CNG can increase or decrease maintenance costs, depending on the particular vehicle, application, and mechanic (Lemmons 2009). NREL models both scenarios by setting both CNG and diesel maintenance costs equal (at $\$ 0.50$ per mile), then increasing $\mathrm{CNG}$ maintenance cost to $\$ 0.75$ per mile $(150 \%)$, and then decreasing them to $\$ 0.25$ per mile $(50 \%)$.

Figure 18 shows that a $50 \%$ change in vehicle maintenance cost makes a big difference in project profitability. These costs are tracked on a per-mile basis, so they quickly add up to some very large costs in fleets where there are a lot of miles driven. This is one of the few costs that, by changing up or down $50 \%$, can make a school CNG fleet more profitable than a refuse fleet. This is also one of the few costs that can make a school project not pay off no matter how large the fleet is. So school bus fleets that travel a lot of miles realize more cost benefits from CNG.

Notice that the $100 \%$ line is much closer to the $50 \%$ line than the $150 \%$ line, which indicates a given reduction in maintenance costs has a larger impact on project economics if the starting $\mathrm{CNG}$ maintenance cost is greater than the diesel maintenance costs. 


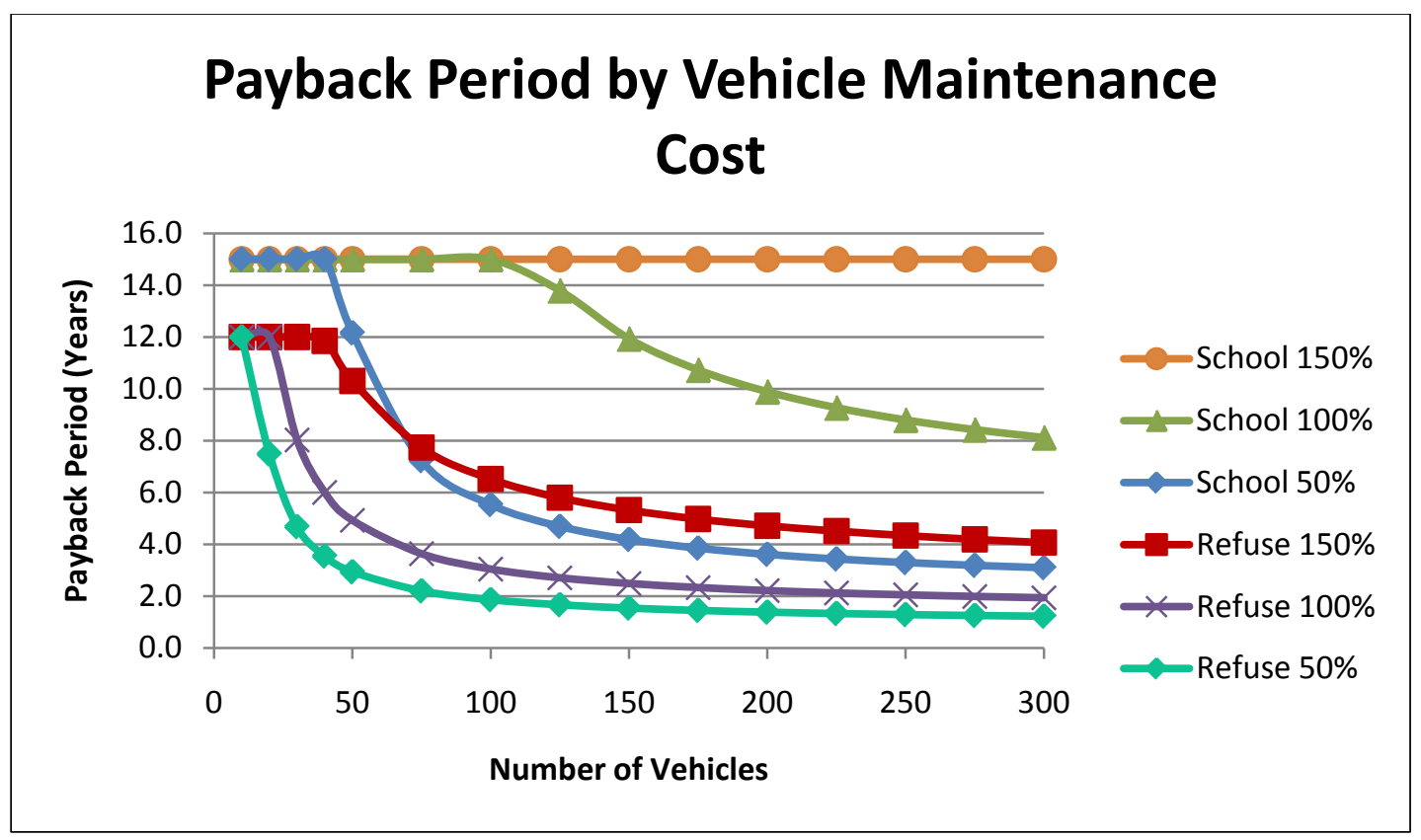

Figure 18. Payback period by vehicle maintenance cost

\section{What if I have to hire a hostler or attendant?}

The VICE model's baseline assumes that fleets will not encounter additional staff costs when they switch from diesel to CNG. However, numerous circumstances can contribute to the need for more hostlers or attendants at the CNG station. There is also a case where a fleet can eliminate hostlers if they use slow-fill. To test the effect of hiring or firing personnel, NREL ran the model from a two-hostler reduction to a four-hostlers addition and looked at how that affects the number of vehicles a fleet needs for a 7-year payback. The results are shown in Figure 19.

The hostler is assumed to cost $\$ 24$ per hour when benefits are added. He is assumed to work an 8-hour shift 5 days a week, and additional refueling is done by the drivers before or after their routes. Therefore, the addition of a hostler costs school and refuse fleets $\$ 4,200$ per month or about $\$ 50,000$ per year.

For the transit and refuse fleets, each hostler required 4 additional vehicles to pay himself off in 7 years. Because both of these numbers are less than a hostler can handle, these fleets should never limit their number of CNG buses based on what their current staff can handle. It seems to be a sound decision to increase staff to accommodate as many $\mathrm{CNG}$ vehicles as possible.

Each hostler for a school fleet required 55 additional buses. Therefore, it would only make sense to hire an additional hostler if he can service 55 buses or more. 


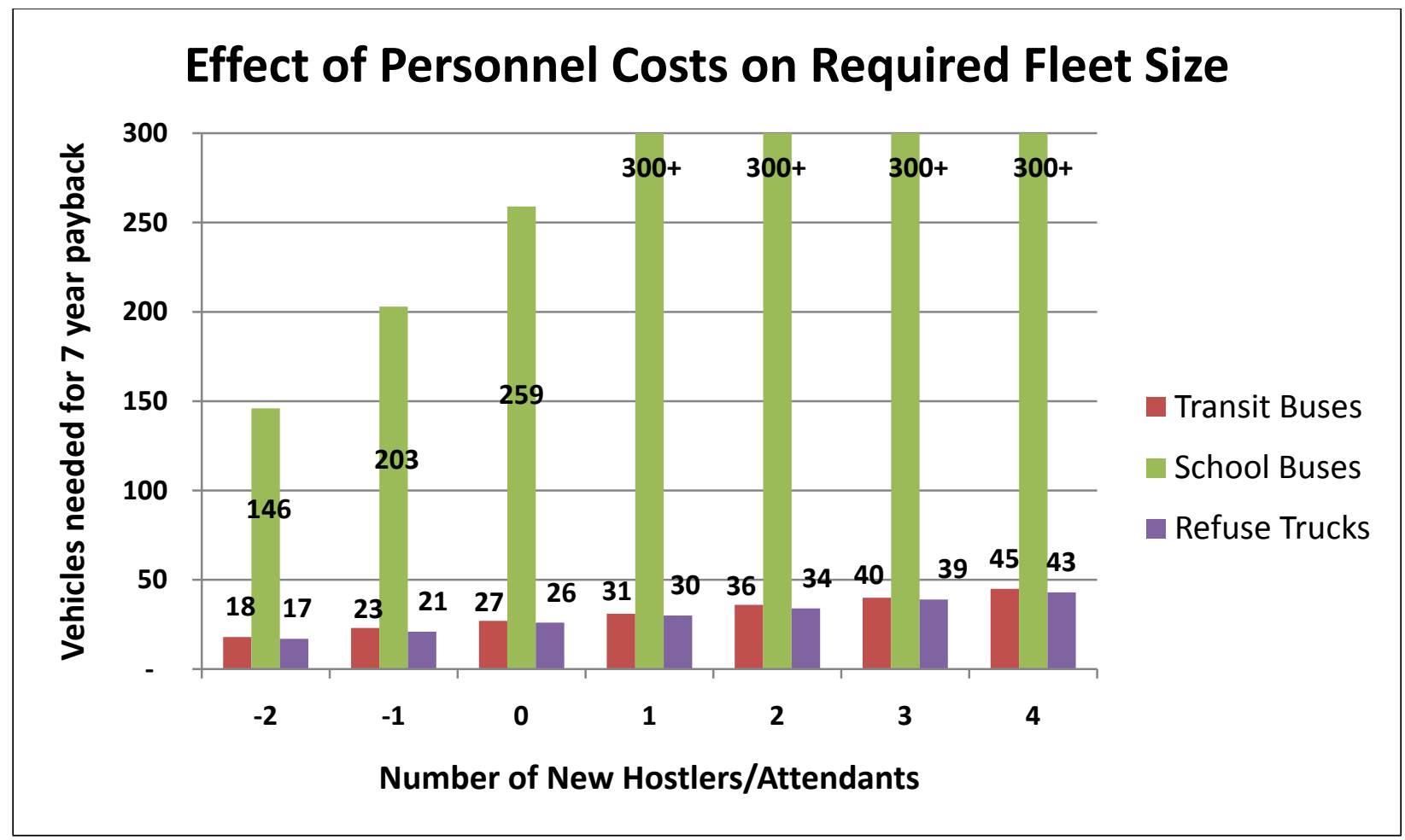

Figure 19. Effect of personnel costs on required fleet size

\section{What if I open my refueling station to the public?}

Opening a refueling station to the public changes the project economics in a number of ways that are listed below. There is too much variability to model all of these factors in one scenario, but each factor was modeled independently in response to questions earlier in the report.

1. Many project grants are tied to the station opening to the public. This is the same as if the upfront station cost was reduced, as modeled for this question: "What happens if the price of my station changes?"

2. Excess capacity may be added to the station to accommodate public vehicles refueling at the same time as the primary fleet. Other equipment such as card readers may also be necessary. These both add to the upfront cost, which is also modeled in the "What happens if the price of my station changes?" section.

3. The refueling window might need to be expanded to accommodate public vehicles. Increased refueling windows were modeled when answering this question: "What happens as I have more or less time to refuel?"

4. The number of attendants must be increased to facilitate sales to the general public. This increase is also modeled in the "What if I have to hire a hostler or attendant?" section.

5. Opening to the public will likely increase wear and tear on station equipment. This increase is explored under this question: "What if my maintenance costs increase or decrease?" 
6. A profit can be made on each GGE of CNG sold to the public. The profit on each gallon affects the firm's finances the same as if the price of diesel went up so the firm saved more money on each gallon of CNG used. This impact is very significant, as shown in the "What will a change in diesel prices do to my payback period?" section.

\section{How do electricity prices change my project economics?}

Not much. Increasing electricity prices $50 \%$ increased the payback period a maximum of 0.7 years (for a 100-bus school fleet) or 0.5 years (for a 20 -truck refuse fleet).

\section{How do station maintenance costs change my project economics?}

Maintenance costs affect project economics more than electricity prices, but they are still not very influential. Increasing maintenance costs $50 \%$ increased payback time for a 100 -school bus fleet by 2.7 years and a 300 -school bus fleet by 0.7 years. The same cost increase resulted in one additional year to pay back for a 30 -truck refuse fleet and only 0.1 additional years to pay back a refuse fleet of 125 or more trucks.

\section{Conclusions}

As with all fleet projects, predicting whether a project is financially sound is challenging but critically important. Decisions made on equipment purchases, capital upgrades, and fuel contracts have long-term impacts on the operational success of the fleet. NREL has modeled the impact of these decisions and other fleet parameters with its VICE model and analyzed fleet projects. When these parameters are compiled as a fleet, the fleet can be classified as "Resilient," "Marginal," or "No-CNG." Resilient fleets tend to use a lot of fuel and are profitable enough to be resilient to multiple changes in fleet parameters. Marginal fleets are profitable but can quickly become unprofitable if parameters change. No-CNG fleets are ones for which CNG would be an unprofitable proposition.

Larger transit and refuse fleets ( $75+$ vehicles) tend to be profitable and resilient to variations in project parameters. This is because the miles driven by the fleet overall use enough fuel to magnify the benefits of the lower-price CNG to offset the entry costs of $\mathrm{CNG}$ (vehicle incremental costs and infrastructure costs). Their payback period only rises above 5 years when diesel drops below $\$ 2.25 /$ gallon, vehicle incremental costs are doubled, $\mathrm{CNG}$ vehicle maintenance costs increase 50\%, VMT drops below 26,000 miles/year (transit) or 14,000 miles a year (refuse), vehicle incremental costs are doubled, or when these factors combine. 


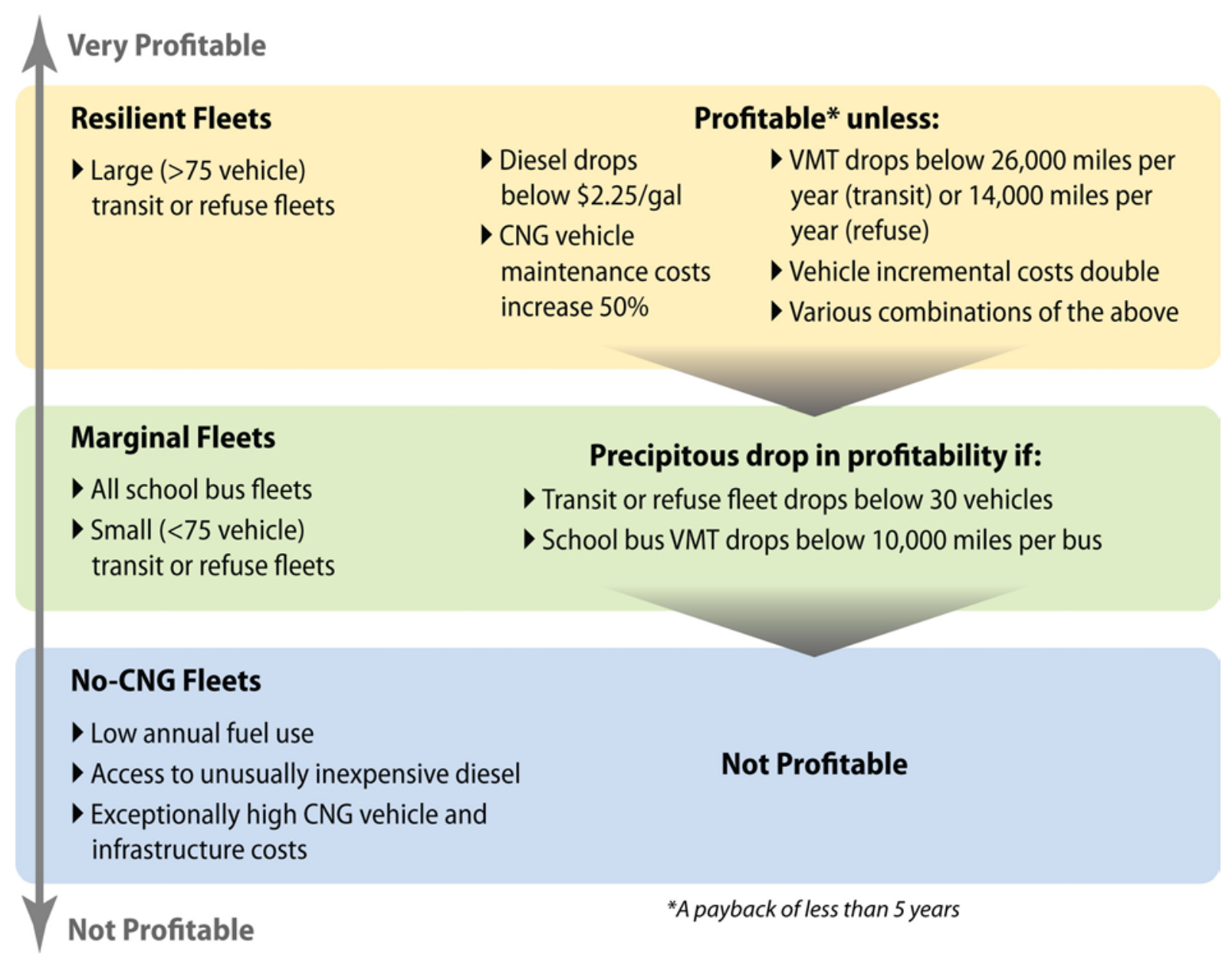

Figure 20. Largest factors affecting the profitability of marginal and resilient fleets

In general, school fleets and small transit/refuse fleets tend to be marginal. Marginal fleets are heavily influenced by many factors, but their profitability drops precipitously if the number of transit/refuse vehicles drops below 30. School fleets have no clear cutoff point for the number of buses, but their profitability deteriorates rapidly if the VMT drops below 10,000 miles per bus because of the overall low fuel use of the fleet.

Fleet type makes a large difference in profitability. At any given fleet size, refuse projects are slightly more profitable than transit projects, and both are much more profitable than school buses. Mixed fleets are more profitable than the mid-point between the individual component fleets, which is particularly helpful for school buses.

Diesel prices are a powerful indicator of profitability given that natural gas prices are relatively consistent. A school bus project appears to only make economic sense once diesel prices approach \$4/gallon for 100-bus fleets and \$5/gallon for 50-bus fleets. For transit and refuse fleets, the size and fleet type become increasingly irrelevant as the price of diesel increases past $\$ 2.50$. For prices below $\$ 2.50$, larger fleets are favored, and refuse fleets are favored over transit. Our current diesel price of $\$ 2.56$ is on a transitional point of the payback curve for transit and 
refuse fleets. If diesel prices stay where they are or rise, project economics look resilient, and if they fall, the economics look marginal.

Per-vehicle VMT is almost as strong an indicator of profitability as the number of vehicles for school fleets. However, VMT is not a relevant factor in transit or refuse fleets unless their VMT is reduced to $1 / 3$ of the average fleet's VMT.

Project success is very sensitive to vehicle maintenance costs. Doubling these costs increases the payback period of the least-sensitive fleet from 1.7 years to 3.3 years. Doubling them can also make a school project not pay off no matter how large the fleet is.

An increase in vehicle incremental cost has a large effect on project profitability. A reduction in incremental cost has a much smaller impact on profitability because most of the amount up to the base case was subsidized by the government, and very little of the amount over the base case is subsidized.

Tax issues have a strong influence on profitability. There are synergies with the vehicle and fuel tax credits, so together, they reduce the payback period of a project more than the sum of both of their impacts. Taking either one of the tax credits away makes school projects not pay off. If a fleet has to pay taxes on diesel but not $\mathrm{CNG}$, their payback period is reduced by $22 \%$.

The cost of the station has a significant influence on the profitability of marginal projects. In general, a 50\% increase in station cost results in a 30\% increase in payback years. This could be make-or-break for many school fleets and smaller ( $<50$ vehicle) transit and refuse fleets.

Factors that don't have much effect on project profitability over the range tested are:

- Efficiency difference between CNG and diesel engines ( $-25 \%$ to $+10 \%)$

- Change in vehicle/project life (10 years to 20 years)

- Electricity prices (50\% and $150 \%$ baseline)

- Maintenance costs for CNG station (50\% and $150 \%$ baseline)

- Garage upgrade (for minimal-upgrade scenario)

- Number of new attendants/hostlers ( -2 to +4 personnel).

These conclusions were derived from testing parameter changes on what NREL deemed a common or average fleet. Synergies between these parameters were not tested and could have surprising effects. To account for these synergies and the specific operating conditions of individual fleets, we encourage fleet managers to use the VICE model when it is posted on the Alternative Fuels and Advanced Vehicles Data Center (www.afdc.energy.gov/afdc/) or to have a CNG infrastructure contractor do an individual assessment of their fleet. 


\section{References}

American Public Transit Association. (2009). Public Transportation Fact Book. www.apta.com/gap/policyresearch/Documents/APTA_2009_Fact_Book.pdf. Accessed March 17, 2010.

American School Bus Council. National School Bus Fuel Data.

http://americanschoolbuscouncil.org/index.php?page=fuel-calculator. Accessed March 17, 2010.

Andre, M. Supervisor of Transportation. Lower Merion School District. Personal communication. August 2009.

Andrews, B. Sales Application Specialist. Autocar. Personal communication. May 2009.

Antila, B. Senior Management Analyst. ValleyMetro RPTA. Personal communication. August 2009.

Chandler, K.; Eberts, E.; Melendez, M. (2006). "Washington Metropolitan Area Transit Authority: Compressed Natural Gas Transit Bus Evaluation." NREL Report No. TP-540-37626; pp. 79.

CVEF 2010. CNG Transit Experience Survey. Report to the National Renewable Energy Laboratory under Task Order KLFH-9-88664-01. Pending NREL review and publication.

Cohen, J.T. (2005). "Diesel vs. compressed natural gas for school buses: a cost-effectiveness evaluation of alternative fuels." Energy Policy (33:13); pp. 1709-1722

EIA 2010a. Petroleum Navigator.

http://tonto.eia.doe.gov/dnav/pet/pet_pri_gnd_dcus_nus_w.htm. Accessed March 10, 2010.

EIA 2010b. Natural Gas Navigator. http://tonto.eia.doe.gov/dnav/ng/ng_pri_sum_dcu_nus_m.htm. Accessed March 10, 2010.

EIA 2010c. Fuel Price Forecasts and Analysis. Tables 12 and 13. www.eia.doe.gov/oiaf/forecasting.html. Accessed March 10, 2010.

Engle, D. (2010). "Fueling with Natural Gas." NGV Fleet Manager, a Supplement to MSW Management; pp. 4.

Federal Transit Administration. (April 2007). "Useful Life of Transit Buses and Vans." Report No. FTA VA-26-7229-07.1. www.fta.dot.gov/documents/Useful Life of Buses Final Report 4-26-07 rv1.pdf. Accessed March 17, 2010.

Gordon, D.; Burdelski, J.; and Cannon J. (2003). "Greening Garbage Trucks: New Technologies for Cleaner Air." Inform, Inc. ISBN \#0-918780-80-2. 
International Fuel Tax Association. Motor Fuel Excise Tax Rates, as of January 1, 2008.

www.taxadmin.org/Fta/rate/motor_fl.html. Accessed March 17, 2010.

Laughlin, M. (2010). Fuel Price Variability Analysis from the Alternative Fuel Price Report.

www.afdc.energy.gov/afdc/price report.html. Accessed April 1, 2010.

Lemmons, J. Director, Equipment \& Performance. Waste Management. Personal

communication. August 2009.

Leonard, J.; Ward, P.F.; Folkman, J.M. (2001). California Clean Fuels.

Market Assessment. (2001). Report No. P600-01-018. California Energy Commission.

http://www.energy.ca.gov/reports/2001-09-18 600-01-018.PDF.

Linder, P. Director of Transportation Services. Kern County Superintendent of Schools. Personal communication. July 2009.

Marathon Technical Services. (2006). Designing New Transit Bus Garages to be Fuel Flexible. White paper. www.afdc.energy.gov/afdc/pdfs/bus_garage design.pdf.

San Antonio. (May 30, 2007). Request for Council Action from the Purchasing and Contract Services Department. http://epay.sanantonio.gov/agendabuilder/RFCAMemo.aspx?RId=1762.

Union of Concerned Scientists. (2003). Alternative Fuel School Bus Fact Sheet. www.ucsusa.org/clean_vehicles/technologies and fuels/gasoline and diesel/alternative-fuelschool-buses.html. Accessed March 17, 2010.

WM Financial Strategies. Municipal Market Data Index $20^{\text {th }}$ Year Maturity by Rating Grade. Tables 1-4 in Rates Over Time-Interest Rate Trends http://www.munibondadvisor.com/market.htm. Accessed March 17, 2010.

NGVAmerica. (June 18, 2008). Fact Sheet: Federal Incentive for Alternative Fuel Use/Sale. www.ngvc.com/pdfs/FederalFuelTaxCredit06-08.pdf. Accessed March 17, 2010. 


\section{Glossary and Acronyms}

Capacity charge-Also termed "demand charge," it is the charge that an electric utility charges a customer to be ready to meet the customer's demands immediately. It is therefore dependent on how quickly the customer pulls electricity out of the grid.

Compressed natural gas $(\mathrm{CNG})$ - A gas, consisting primarily of methane, that is compressed to allow more energy to fit into a smaller fuel tank.

Diesel-gallon equivalents (DGE) - The amount of energy that is in 1 gallon of diesel fuel. This is larger than a GGE.

Federal Transit Administration (FTA) - An agency within the United States Department of Transportation (DOT) that provides financial and technical assistance to local public transit systems.

Gasoline-gallon equivalents (GGE) - The amount of energy that is in 1 gallon of gasoline. CNG is typically measured in this unit.

Hostler-A person who refuels, cleans, and performs regular maintenance for a fleet of buses or trucks at the end of the day.

Net present value (NPV) - The difference between the present value of cash inflows and the present value of cash outflows. All present-value cash flows have been discounted so that recent flows are worth more than future flows.

National Renewable Energy Laboratory (NREL) — One of the U.S. Department of Energy's 16 national laboratories, NREL is the primary laboratory for renewable energy and energy efficiency research and development.

Rate of return (ROR) - The gain or loss on an investment over a specified period expressed as a percentage increase over the initial investment cost (investopedia.com).

Refueling window-The period of time in which vehicles are available to refuel.

Vehicle-miles traveled (VMT) - The number of miles traveled by 1 vehicle in 1 year.

Vehicle and Infrastructure Cash-Flow Evaluation (VICE) model-An NREL-built model that assesses the profitability of investing in alternative fuel infrastructure under for various fleets. NREL plans to expand the VICE model to assess more fuels than CNG. 


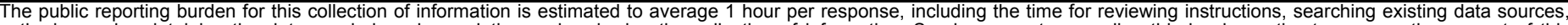

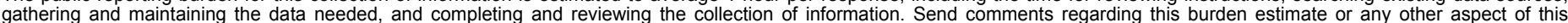

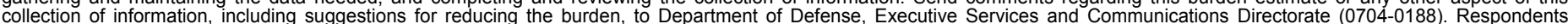

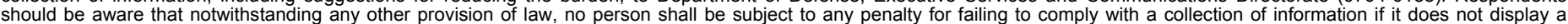

should be aware that notwithstanding

PLEASE DO NOT RETURN YOUR FORM TO THE ABOVE ORGANIZATION.

\begin{tabular}{l|l|l|l} 
1. REPORT DATE $(D D-M M-Y Y Y Y)$ & 2. REPORT TYPE & 3. DATES COVERED (FrOm - TO)
\end{tabular} June 2010

Technical Report

4. TITLE AND SUBTITLE

Business Case for Compressed Natural Gas in Municipal Fleets 5a. CONTRACT NUMBER

DE-AC36-08-GO28308

5b. GRANT NUMBER

5c. PROGRAM ELEMENT NUMBER

5d. PROJECT NUMBER

NREL/TP-7A2-47919

5e. TASK NUMBER

FC08.0032

5f. WORK UNIT NUMBER
7. PERFORMING ORGANIZATION NAME(S) AND ADDRESS(ES)

National Renewable Energy Laboratory

1617 Cole Blvd.

Golden, CO 80401-3393
8. PERFORMING ORGANIZATION REPORT NUMBER

NREL/TP-7A2-47919

9. SPONSORING/MONITORING AGENCY NAME(S) AND ADDRESS(ES)

10. SPONSOR/MONITOR'S ACRONYM(S) NREL

11. SPONSORING/MONITORING AGENCY REPORT NUMBER

12. DISTRIBUTION AVAILABILITY STATEMENT

National Technical Information Service

U.S. Department of Commerce

5285 Port Royal Road

Springfield, VA 22161

13. SUPPLEMENTARY NOTES

14. ABSTRACT (Maximum 200 Words)

This report describes how NREL used the CNG Vehicle and Infrastructure Cash-Flow Evaluation (VICE) model to establish guidance for fleets making decisions about using compressed natural gas.

15. SUBJECT TERMS

compressed natural gas; CNG; municipal fleets; CNG Vehicle and Infrastructure Cash-Flow Evaluation model; Vehicle and Infrastructure Cash-Flow Evaluation; VICE; VICE model

\begin{tabular}{|c|c|c|}
\hline \multicolumn{3}{|c|}{ 16. SECURITY CLASSIFICATION OF: } \\
\hline $\begin{array}{l}\text { a. REPORT } \\
\text { Unclassified }\end{array}$ & $\begin{array}{l}\text { b. ABSTRACT } \\
\text { Unclassified }\end{array}$ & $\begin{array}{l}\text { c. THIS PAGE } \\
\text { Unclassified }\end{array}$ \\
\hline
\end{tabular}

\begin{tabular}{|c|c|} 
17. LIMITATION & 18. $\begin{array}{l}\text { NUMBER } \\
\text { OF ABSTRACT } \\
\text { OF PAGES }\end{array}$ \\
&
\end{tabular}

19a. NAME OF RESPONSIBLE PERSON

19b. TELEPHONE NUMBER (Include area code) 